FEDERAL RESERVE BANK OF SAN FRANCISCO

WORKING PAPER SERIES

\title{
Did Consumers Want Less Debt? Consumer Credit Demand Versus Supply in the Wake of the 2008-2009 Financial Crisis
}

\author{
Reint Gropp \\ Goethe University Frankfurt \\ John Krainer \\ Federal Reserve Bank of San Francisco \\ Elizabeth Laderman, \\ Federal Reserve Bank of San Francisco
}

February 2014

Working Paper 2014-08

http://www.frbsf.org/economic-research/publications/working-papers/wp2014-08.pdf

The views in this paper are solely the responsibility of the authors and should not be interpreted as reflecting the views of the Federal Reserve Bank of San Francisco or the Board of Governors of the Federal Reserve System. 


\title{
Did Consumers Want Less Debt? Consumer Credit Demand Versus Supply in the Wake of the 2008-2009 Financial Crisis
}

\author{
Reint Gropp, John Krainer, and Elizabeth Laderman ${ }^{1}$
}

January 2014

\begin{abstract}
We explore the sources of household balance sheet adjustment following the collapse of the housing market in 2006. First, we use microdata from the Federal Reserve Board's Senior Loan Officer Opinion Surveyto document that banks cumulatively tightened consumer lending standards more in counties that experienced a house price boom in the mid-2000s than in nonboom counties. We then use the idea that renters, unlike homeowners, did not experience an adverse wealth shock when the housing market collapsed to examine the relative importance of two explanations for the observed deleveraging and the sluggish pickup in consumption after 2008. First, households may have optimally adjusted to lower wealth by reducing their demand for debt and implicitly, their demand for consumption. Alternatively, banks may have been more reluctant to lend in areas with pronounced real estate declines. Our evidence is consistent with the second explanation. Renters with low risk scores, compared to homeowners in the same markets, reduced their levels of nonmortgage debt and credit card debt more in counties where house prices fell more. The contrast suggests that the observed reductions in aggregate borrowing were more driven by cutbacks in the provision of credit than by a demand-based response to lower housing wealth.
\end{abstract}

\footnotetext{
${ }^{1}$ The authors are respectively from the Goethe University Frankfurt, Federal Reserve Bank of San Francisco, and Federal Reserve Bank of San Francisco. The views expressed are those of the authors and not necessarily those of the Federal Reserve Board of Governors or the Federal Reserve Bank of San Francisco. For many helpful comments we thank Meta Brown, Amy Crews Cutts, Galina Hale, Simon Kwan, Rob Valletta, Jim Wilcox, and seminar participants at the Federal Reserve Board of Governors, George Washington University, the System Conference on Applied Micro, the European Economics Association Summer Meetings, and the Boulder Summer Conference on Financial Decision Making.
} 


\section{Introduction}

Between 2008 and 2012, total household debt fell by about 6\%, and debt-to-income by about $10 \% .^{2}$ These household balance sheet adjustments are thought to have weighed on aggregate consumption as the U.S. economy has struggled to emerge from the downturn. A recent paper by Mian, Rao, and Sufi (2012) uses regional variation to assemble evidence on the links between declines in housing wealth, deleveraging, and changes in consumption expenditures after the 2008-2009 financial crisis. Mian, Rao, and Sufi (MRS in the following) argue that the combination of a large accumulation of household debt in counties with high house price appreciation before the mortgage crisis (here, "boom” counties) and the subsequent sharp decline in house prices in roughly the same counties resulted in household deleveraging and a concomitant reduction of household consumption expenditure. In support of their story, MRS show that household consumption expenditures declined more in boom counties than in non-boom counties.

One question that remains in this line of research is how the household deleveraging was accomplished. MRS do not systematically disentangle two possible, not necessarily mutually exclusive mechanisms of deleveraging. One possible mechanism for consumer deleveraging stems from a demand-side story. In a simple model of household consumption planning, homeowners would optimally choose to reduce their lifetime consumption, and thereby reduce their household debt, on perceiving a negative and permanent shock to their housing wealth. ${ }^{3}$ The second mechanism for household deleveraging focuses on credit supply. This story posits

\footnotetext{
${ }^{2}$ Federal Reserve Flow of Funds and National Income and Product Accounts, 2008.Q3-2012.Q1.

${ }^{3}$ One alternative demand story is that homeowners with limited self-control may increase home equity borrowing when house prices climb in order to finance greater current consumption (Laibson 1997) and then cut back on current consumption and borrowing, perhaps out of remorse or excess prudence, when house prices fall.
} 
that households, homeowners and non-homeowners alike, are forced to de-lever because banks are unwilling to lend to them, refinance their mortgages, or roll over existing debt. ${ }^{4}$ The difference may have first order policy implications. ${ }^{5}$ If households optimally adjust to what they perceive to be a permanent shock to their wealth, consumption may be very slow to adjust back to pre-crisis levels going forward. Policymakers may find it difficult to offset these household decisions. If, on the other hand, households are constrained because of banks' unwillingness or inability to lend, then consumption may recover quickly once the frictions in credit markets have been alleviated and credit quality has improved. MRS discuss the possibility that both demand and supply factors may be at work, but they do not attempt to explicitly determine their relative importance. ${ }^{6}$

To set the stage for our analysis, Figure 1 presents the cumulative tightening from 2008 through 2012 of lending standards in boom versus non-boom counties for consumer installment loans and credit card loans from the Federal Reserve Board's Senior Loan Officer Opinion Survey (SLOOS). ${ }^{7}$ For both loan categories, banks tightened lending standards markedly more

\footnotetext{
${ }^{4}$ Mortgage refinancing usually decreases mortgage debt. But it can also be accompanied by an increase in total household debt through, for example, a more than offsetting increase in credit card spending.

${ }^{5}$ One other source of deleveraging came through the mortgage foreclosure process. More than four million foreclosures have taken place since the housing crisis began, with the houses backing the defaulted mortgages remaining vacant or sold for considerably lower amounts. This process has had a large impact on bank profits, but, going forward, prospects for economic growth are more closely linked to the decisions of non-defaulting households regarding desired spending and borrowing and the willingness of banks to lend to this population.

${ }^{6}$ A credit provision story can be told without appealing to the high level of pre-crisis household debt that MRS argue plays an instrumental role in deleveraging. A credit provision story with elevated pre-crisis debt can be told with constrained homeowners. The increase in house prices may have significantly loosened borrowing constraints on homeowners, increasing markedly their ability to smooth consumption. When house prices fell, borrowing constraints would have returned to being more binding. (Agarwal, Liu, and Souleles (2007) estimate that the percent of constrained consumers in their sample of credit card holders receiving tax rebates is about $25 \%$.)

${ }^{7}$ Even in the credit card market, there is scope for geographic variation in credit standards. Stango (2002) finds empirical evidence of switching costs for consumers in the credit card market. In addition, only the top 50 of the 250 largest credit card issuers operate nationally. (Stango (2002), p. 481.)
} 
in boom counties than in non-boom counties. ${ }^{8}$ This evidence supports the notion that credit extension to consumers was significantly more restrictive in boom counties than in non-boom counties in the aftermath of the 2008-2009 financial crisis. However, a tightening of credit standards by itself does not tell us much about the economic importance of tighter standards. It may still be the case that the overwhelming reduction in household leverage came about because households demanded less debt. In that case the tighter standards would not have been binding and by themselves may not have contributed to the deleveraging.

Hence, in this paper we attempt to explicitly assess the relative economic importance of credit supply in explaining the recent decline in household debt. Using individual credit file data from 1999 through 2008, we estimate a model of the level of debt in which we control for many factors likely to affect the demand for debt. We confirm the reasonableness of the empirical results we obtain from estimating that model and demonstrate that the distribution of predicted

\footnotetext{
${ }^{8}$ Figure 1 was prepared as follows: Every quarter, the SLOOS asks a panel of large and medium-sized banks how their credit standards and terms have changed over the past three months. Banks are asked to rate the direction and extent of any change by picking one of five qualitative answers. For example: banks are asked to pick one of the following answers characterizing the change in their willingness to lend since the preceding survey: much less willing, somewhat less willing, no change, somewhat more willing, or much more willing. For one consumer installment loan question (asking about the bank's change in its willingness to make such loans) and one credit card loan question (asking about the bank's change in lending standards on such loans), we assigned numerical values to each of the five choices and constructed, for each county, an index equal to the sum of the SLOOS banks' responses, with each bank's response weighted by the proportion of the total deposits of SLOOS banks operating in the county that is held by that bank. Our values range from -2, for the most easing of credit conditions, to 2, for the most tightening of credit conditions. For each county, we then calculated running totals of these weighted sums over time to construct the cumulative change in lending conditions since the beginning of 2008. The graphs in Figure 1 depict the mean values of these running totals for boom counties and non-boom.

We note the sharp increase in the cumulative tightening of consumer installment loan credit standards in the fourth quarter of 2011 in non-boom counties. The underlying data indicate fairly widespread tightening across the relevant banks. Therefore, we simply accept the sharp increase as a feature of the data.

We also note that each bank's response to the survey likely is weighted by the distribution of its own deposits across boom vs. non-boom counties. In principle, this could temper any correlation between boom counties and changes in credit standards as we measure them. For example, a bank may have a large share of the total deposits in a boom county, but the share of its own deposits in boom counties overall may be small. If such were the case, even though the bank likely would respond on the basis of its being, in general, a non-boom county lender, its response would be heavily weighted in our index for the particular boom county. We observe, however, a strong correlation between county types and changes in credit standards, in the expected direction. A contributing factor may be that, in practice, banks that have large shares of the total deposits in boom counties tend to also have large shares of their own deposits in boom counties.
} 
total debt in boom counties is very similar to its distribution in non-boom counties. We then use a propensity score matching approachto assess the effect of residence in a boom county on the change in debt between 2008 and 2011, controlling for the borrower's actual level of debt in 2008 and the same demand factors as in our levels regression. ${ }^{9}$

We rely on the following idea to determine the relative importance of demand versus credit provision effects. While it may be difficult to separate credit demand and supply effects for homeowners in boom counties, we can make use of the fact that renters did not experience an adverse housing wealth shock in boom counties. Hence, if the difference in deleveraging between renters in boom counties and renters in non-boom counties is greater than the difference between homeowners in boom counties and homeowners in non-boom counties, credit supply effects would appear to dominate demand effects. If on the other hand, the difference between renters in non-boom counties and renters in boom counties is smaller than the difference between the deleveraging of homeowners in boom counties versus that of homeowners in non-boom counties, we cannot exclude that demand effects dominate, although supply effects may still play a significant role. Hence, our identification of credit supply effects relies on a difference in differences term. The first difference is the one between boom and non-boom counties and the second the difference between homeowners and renters.

Our results indicate that credit supply effects are first order and may dominate demand effects. Controlling for demand for debt using our methodology, we find that the difference in deleveraging for renters in boom and non-boom counties is larger than the difference between

\footnotetext{
${ }^{9}$ Since house price changes during the crisis were highly correlated with pre-crisis house price appreciation (that is, whether or not a county was a boom county, (Figure 7)), we are, in essence, assessing the effect of house price changes between 2008 and 2011 on the change in debt between 2008 and 2011. We follow MRS in differentiating counties according to their degree of pre-crisis house price appreciation (high versus low) instead of according to their crisis era house price changes.
} 
homeowners in boom and non-boom counties. We argue that as renters were not hit by an adverse wealth shock, and controlling for the economic environment they face, this difference must be due to differences in the availability of credit in boom versus non-boom counties. We further show that the bulk of the deleveraging observed in boom counties does not come from households that own a home. In contrast, a demand story based on housing wealth would predict that homeowner borrowers would de-lever more than renter borrowers in boom counties. Consistent with a supply story, we also find that boom county deleveraging is more pronounced for households with lower risk scores. Indeed, for credit card and auto debt, there is very little difference in deleveraging between boom and non-boom counties associated with borrowers with an average risk score. For borrowers with above average risk scores, deleveraging is actually less in the boom counties than in the non-boom counties. ${ }^{10}$

This paper is an empirical microeconomic investigation. We have in mind a general consumption smoothing framework. A sharp unanticipated drop in house prices may cause leveraged households to want to reduce debt by way of a standard wealth effect. In addition, the drop in collateral values may reduce the provision of credit to households, which may result in a larger reduction in debt than the wealth effect alone would have generated. Decreases in the provision of credit due to the collateral channel are consistent with arguments in Eggertsson and Krugman (2011) and Midrigan and Philippon (2011). Of course, reduced credit provision may have had various sources during this period. For example, see Damar et al. (2012) for an

\footnotetext{
${ }^{10}$ Our paper also provides empirical evidence regarding households' substitution across debt categories. We find that, not surprisingly, mortgage debt levels in boom counties are higher than in non-boom counties. However, other types of debt, including auto, consumer, and credit card debt, tend to be lower in boom counties compared to nonboom counties. Overall debt levels between households in boom counties and non-boom counties differ less than the difference in mortgage debt levels would suggest. If house prices rise very rapidly, and there is no corresponding adjustment in income, households are forced to spend a larger portion of household income to finance housing. This leaves less debt capacity for other debt-financed consumption. Mortgage and non-mortgage debt are substitutes in households' total debt.
} 
empirical investigation using Canadian data of the effect of bank financial distress on household consumption. In addition, see Dynan and Edelberg (2013) for a comprehensive list of potential supply and demand factors that may affect household leverage, and Bhutta (2013) for evidence of decreases in the supply of mortgage credit since the housing bust. Black, Stein, and Zafar (2013) also use the FRB-NY Consumer Credit Panel to report interesting differences in the way different demographic groups (e.g., older and prime homeowners) substituted between home equity and credit card debt over the sample period. While they do not attempt to disentangle credit supply from credit demand, they find evidence of collateral effects on debt accumulation throughout the housing market boom and bust periods.

We complement the growing literature that links household debt, household wealth, and consumption with a focus on the recent recession. For example, Carroll (2013), Eggertson and Krugman (2012), Guerrieri and Lorenzoni (2011), Hall (2011), and Midrigan and Philippon (2011) all point to a high level of household debt as an important precursor of the Great Recession. In these expositions, a negative shock to household balance sheets, such as an unanticipated drop in house prices, causes households to want to reduce consumption, most simply through the standard wealth effect of a consumption smoothing model without bequest motives. ${ }^{11}$ Simply as a matter of accounting, if consumption had been at least partially financed by debt, households would also reduce debt. ${ }^{12}$ In order for the models in these papers to generate meaningful reductions in debt and consumption economy-wide, the authors posit that ex ante

\footnotetext{
${ }^{11}$ See Davis and Palumbo (2001) for a discussion of wealth effects in consumption smoothing models.

${ }^{12}$ If consumption had been fully financed by a portion of liquid wealth, and the negative shock decreases liquid wealth by more than the contemporaneous decline in desired consumption, then debt will actually need to increase from zero for a time in order to maintain a smooth consumption path. However, housing wealth is not liquid. If one wants to use increases in house prices to finance increases in consumption before one is ready to sell a house, one must use a debt instrument. On the flip side, a decrease in consumption that is generated by a decrease in house prices will be accompanied by a decrease in total debt.
} 
heterogeneity among households generates levels of debt that were elevated before the shock. Frictions such as the zero lower bound on nominal interest rates dampen the countervailing positive effect of shock-generated falling interest rates on credit demand and, consequently, on consumption. We show, however, that the effect coming from bank balance sheets and the consequent restriction in credit supply may have been at least as important as the channel these papers point to. Additional empirical evidence linking high levels of household debt to economic downturns in a macroeconomic context can be found in Glick and Lansing (2009, 2010), Jorda et. al. (2012), and Mian and Sufi (2010).

The paper is organized as follows. In section two we describe the data. In section three, we present the results of our pre-crisis debt level regressions and in section four, our post-crisis debt change regressions. Section five concludes.

\section{Data}

The data come from Equifax, a large credit reporting agency. The data span 1999.Q1 to 2011.Q4, and contain a large amount of information on consumer liabilities--mortgage, home equity, auto, credit card, etc., and some borrower characteristics such as age, risk score, and delinquency status on their liabilities. ${ }^{13}$ All analysis is based on data from the Federal Reserve Bank of New York's Consumer Credit Panel, which is a five percent random sample of consumers with credit histories that is nationally representative in a given quarter and also

\footnotetext{
${ }^{13}$ The risk score is the Equifax Risk Score.
} 
designed to reproduce the transitions of young and old into and out of the credit pool. ${ }^{14}$ To make the dataset more manageable we used a 10 percent random sample of the Consumer Credit Panel, implying a .5 percent random sample of the U.S. population with credit histories. Consumers are located by the zip code of their home mailing address. After identifying the county of each residence and merging with house price indices available from CoreLogic, our sample consists of over 900,000 individuals living in more than 1,100 counties across the country.

The distribution of entry and exit into our sample may be seen in Figures 2 and 3. On average, about 3,000 new credit histories appear in our sample each quarter, offset somewhat by about 2,300 history terminations each quarter, so that our sample is slowly growing over time. ${ }^{15}$ The commencement of a borrower history, however, does appear closely related to age. The new borrowers entering the sample had a median age of about 28, a number which trended downward over the sample period. Newly appearing borrowers had median risk scores of about 660, well below the overall sample median of 712 .

Only one-third of our sample of consumer histories spans the full 1999.Q1 - 2011.Q4 period. While this is still a substantial amount of data, in this analysis we use the entire, unbalanced panel to allow some of the compositional changes that we experienced over the 2000s to enter into the analysis. As alluded to above, many of the new entrants to the panel were young households with low risk scores. These household borrowers were particularly susceptible to the economic volatility that occurred at the end of our sample and we will want their credit experiences present in our data. In many ways, this group bore the brunt of the shock

\footnotetext{
${ }^{14}$ See Lee and Van der Klaauw (2010) for a description of the sampling methodology used in the construction of the Consumer Credit Panel.

${ }^{15}$ Termination of a borrower record could take place for a variety of reasons, including death or instances where a trade line (credit type) has no recorded activity for a length of time greater than Equifax's predefined limits. Also, the Consumer Credit Panel draws from borrowers with specific sequences of digits in their social security numbers. If an individual changes their social security number, they could drop out of the sample.
} 
that hit the U.S. housing market starting in 2006. By contrast, a more seasoned homeowner that bought in 1999 and stayed in the house most likely experienced net house price appreciation over the entire period. ${ }^{16}$ Indeed, average risk scores for borrowers present for the entire sample period actually increased over the 13-year period, whereas average risk scores for the population at large fell quite notably.

For a first glimpse at the loan balance data, we compare the Flow of Funds data to the aggregated totals in our sample. While the match is not perfect, the correlation of our total mortgage series (Figure 4) and total nonmortgage debt series (Figure 5) with the Flow of Funds counterpart is quite high. Throughout, we define nonmortgage debt as the sum of auto, credit card, and other nonmortgage consumer loan balances outstanding, excluding student debt. ${ }^{17}$ This particular concept of nonmortgage debt does not match the dynamics of the Flow of Funds, because we do not include student loans in our measure. This choice was made because of the uncertainties measuring student loan debt as well as our desire to focus on a nonmortgage debt series that is plausibly linked to debt put in place to finance consumption.

Through the course of our sample period, total mortgage debt more than doubled, peaking in 2008 and then falling by about 10 percent. Nonmortgage debt declined somewhat more, as balances fell 15 percent from the peak, led primarily by a 20 percent decline in credit card balances. This development in credit card balances is significant in that it was not accomplished through "involuntary deleveraging," as when debts are expunged following a mortgage foreclosure. Rather, the declines in nonmortgage indebtedness reflect either a

\footnotetext{
${ }^{16}$ Of course, the same homeowner may still have changed leverage over the period and become underwater relative to their mortgage debt despite the overall price appreciation.

${ }^{17}$ Our nonmortgage consumer debt excludes any consumer debt secured by a house, so it excludes, for example, home equity debt.
} 
reluctance of consumers to borrow or a reluctance of lenders to fund the previous levels of consumer debt, or both.

Following MRS, our debt level regressions use the estimates from Saiz (2010) of the elasticity of local housing supply with respect to price as a way of controlling for exogenous features of the land that might lead to differential house price levels and, hence, differences in debt. For example, MRS present empirical evidence that, in counties with highly inelastic housing supply and rapidly increasing house prices during the boom, homeowners were especially likely to increase their debt. We manually link the 806 MSA-level elasticity estimates in Saiz to the counties in our data set. About 10 percent of our observations are from locales not covered by Saiz. Inspection reveals that the vast majority of these match failures are in less populated areas. To conserve data, we assigned an imputed elasticity equal to the sample maximum in for these observations and included a missing elasticity dummy variable in all our debt level regression specifications.

At the individual borrower level, our debt level regressions include the number of inquiries made to Equifax over the preceding four quarters regarding the consumer's credit record as well as the borrower's age and risk score. The inquiries are usually made as a result of the consumer seeking more credit and therefore are a useful gauge of overall credit demand.

Finally, we use information from the U.S. Census Bureau’s latest five-year American Community Survey (ACS), based on pooled data from 2006 through 2010. These demographic data are at the census tract level. All of the variables here are meant to proxy for income, wealth, family attributes, and the many other factors that would be expected to influence an individual's demand for credit independent of their influence through changes in credit record inquiries. 
Many of our demographic variables are the same as those in Cohen-Cole (2011) and Musto and Souleles (2006).

For a summary of the developments of the debt levels of households see Table 1 . All statistics in the table are conditional on having non-zero levels of the respective type of debt. The table gives a first glimpse at the results that will emerge later in the paper. It shows that debt levels of the median household increased from 2002 to 2008 to \$17,000 and then dropped again to the 2002 level of $\$ 14,000$. It also shows that the decline in total debt is not due to changes in mortgage liabilities. Mortgage debt increased from \$106,000 in 2002 to \$148,000 in 2008, and then increased even further through 2011. A similar pattern can be observed for home equity lines of credit. In contrast, non-mortgage liabilities decline strongly after their peak in 2008, especially for the $75^{\text {th }}$ percentile of the distribution. Deleveraging does not seem to have taken place in mortgage-related debt, even in mortgage-related debt that may be used for consumption, like home equity lines of credit. Table 2 gives some summary statistics on the demographic variables we use in the regressions.

\section{Pre-crisis debt level regressions}

The first step in establishing a benchmark for the demand for credit takes the form of debt level regressions as given by:

$$
D_{i}=\alpha+f\left(X_{i}\right)+\Gamma X+\varepsilon,
$$

where $D_{i}$ is an individual debt category (i.e., total debt, mortgage,...) for individual $i, \mathrm{X}_{i}$ consists of borrower $i$ 's age and risk score and the number of inquiries requesting borrower $i$ 's credit 
report in the previous 12 months, and $X$ is a vector of control variables at the census tract level. ${ }^{18}$ We estimate the above equation as a pooled regression using observations from 1999.Q1 to 2008.Q2, the quarter at which total household debt peaked in our overall sample. All debt categories are in logs. The results from the OLS specifications may be found in Table 3.

The number of credit report inquiries comes in strongly positive in all categories, as expected. Interestingly, we do not find a particularly strong role for the supply elasticity in explaining cross-sectional differences in consumer debt. Only for home equity and credit cards does the elasticity coefficient estimate have both the expected sign and statistical and economic significance that would be fully consistent with MRS. Since we are looking at the individual borrower level and focusing on debt levels—not debt-to-income ratios—-this result is not necessarily a contradiction of the results in the MRS paper. However, this is an important result for our study in that the supply elasticity is one of only two variables in our set of controls that vary meaningfully across counties. As we will see, there are not large differences in our distribution of predicted debt levels across counties when we sort by house price appreciation during the housing boom. This finding is consistent with our finding of a muted role for crosscounty variation in supply elasticity.

The other variable in our set of controls that varies meaningfully across counties is the current unemployment rate. As with all the other controls, the presence of credit report inquiries in the regression complicates interpretation of the coefficients on the unemployment rate. However, we do note that the unemployment coefficient for the home equity and the nonmortgage debt categories is positive. This finding is consistent with the results in Hurst and

\footnotetext{
${ }^{18}$ The regression in equation (1) also contains a complete set of time dummies to capture macroeconomic fluctuations over the period. The individual's age and risk score enter the equation as piecewise linear splines. We do not report the coefficients on the time dummies or on the age or risk score splines.
} 
Stafford (2004), who document household consumption smoothing in the face of income shocks by way of drawing on credit lines—particularly home equity credit.

In addition, we find that the distribution of debt as predicted by our estimated model in boom counties is very similar to its distribution in non-boom counties (Figure 6). Therefore, any debt change results we obtain using our entire sample are likely to confirm our results using our propensity score matched sample. We will take both approaches in the next section.

\section{Post-crisis debt change regressions}

The ultimate objective of this paper is to ascertain whether households in counties with particularly strong pre-crisis house price appreciation reduce their debt because they choose to or because they are unable to obtain the desired amount of credit. Following MRS, we break our sample up into regional groupings according to county house price appreciation during the 20012006 period (Figure 7). We form a group of low appreciation counties that were in the bottom two deciles of boom period house price appreciation ("non-boom" counties). We also form a group of high appreciation counties from the top two deciles of this same distribution ("boom” counties).

We strip out all borrowers who experienced any type of default or a consumer bankruptcy in the post-2008.Q2 period. We do this for a number of reasons. First, default, foreclosure, and bankruptcy are momentous events. Lenders have always responded to these events by limiting or outright denying access to credit for some period of time afterwards. It may be the case that defaulters have been treated even more severely in the recent housing bust than at other times (see Hedberg and Krainer (2012) for evidence that this is the case), but including defaulters in 
our analysis would lead us to overstating a tightening of lending standards. Second, we do not know the motive for a default. From the vantage point of, for example, mortgage demand, a default in response to falling house values is a valid way for borrowers to deleverage and, ideally, should be considered in the analysis. Substantively different, though, is a default following a life event, such as unemployment, poor health, or divorce. This type of default and deleveraging is more of a random shock than a behavioral response, and the latter is the focus of this paper.

Disentangling the demand for credit from the supply of credit is no easy task. Ideally, we would be able to identify consumers with identical demand for credit, but living in counties with different exposures to house price shocks. Further, despite differing house price shocks, we would like all other economic conditions in these different counties to evolve in exactly the same way. In this idealized setting, with underlying credit demand controlled for, differences in household debt changes across the counties would be interpreted as differences in credit availability. Obviously, perfect experimental settings such as this are rare or nonexistent in the housing market.

In order to come as close as possible to this experimental setting, we proceed in two ways. First, we perform a propensity score matching exercise that pairs consumers that are similar in terms of their probability of living in a boom county and in terms of their predicted 2008.Q2 debt level, but are different according to whether they actually live in a boom county or not. We then take a difference-in-differences approach among the matched consumers to investigate whether credit constraints have played a large role in debt changes following the post-2008 boom. Second, we estimate a set of regressions of changes in debt at the individual consumer level that allows us to control for not just proxies for initial period consumer-specific 
credit demand, but also for differences in subsequent changes in the economic environment that might have led to changes in demand as the housing bust and recession set in in mid-2008.

The matching routine is based on a probit model of the assignment of consumers into boom vs. non-boom counties. ${ }^{19}$ Our predictors are the same variables as are in the debt level regression, with the exception that we omit the squared age and risk score terms. The fitted probabilities of living in a boom county are estimated over all consumers present in the data in 2008.Q2. We take slices of the debt distribution to focus on deleveraging amongst the consumers with low debt (less than $20^{\text {th }}$ percentile of total predicted debt in 2008.Q2), medium debt $\left(40^{\text {th }}-60^{\text {th }}\right.$ percentile of total predicted debt in 2008.Q2), and high debt ranges (greater than $80^{\text {th }}$ percentile). For this slicing of the distribution of debt we use predictions of total debt in 2008.Q3 as generated by column (1) of Table 3. Within each of these slices of the debt distribution, we select a resident of a boom county and find the resident in the non-boom counties from the same slice of the predicted debt distribution with the closest probability of (counterfactually) living in a boom county. ${ }^{20}$ For each type of debt we consider in our regressions—-total nonmortgage, auto, credit card—we then compare the change in debt from 2008.Q3 to 2011.Q4 for residents of boom counties to the same difference for their matches in non-boom counties. Finally, we experiment with different matching routines. In the first routine, we match solely on the basis of predicted debt and the fitted probabilities of living in a boom county. We also try a second and a third routine where we match consumers with mortgages over the sample period of interest to other mortgage-holding consumers. We refer to this group as our matched "homeowner" sample. Finally, we match consumers with no

\footnotetext{
${ }^{19}$ We omit borrowers living in counties other than the bottom two and top two deciles from all of the empirical analyses from here on in the paper.

${ }^{20}$ We match with replacement.
} 
mortgage at all during the sample period of interest to other consumers with no mortgage. This group is our matched "renter" sample.

The results from the probit estimation may be found in Table 4. The three household variables that we have are age, risk score, and credit record inquiries. The results suggest that consumers living in boom counties have slightly higher risk scores, on average, and a somewhat higher rate of credit record inquiries. As of 2008, the geographic controls identify the boom counties as having census tracts with somewhat better economic conditions as given by a higher incidence of small business activity, lower unemployment, and lower shares of households living on food stamps.

In Figures 8a-b we plot the kernel density estimates of the fitted probabilities of living in a boom county, conditional on actual county of residence. For these figures, we also impose the restriction that the predicted total consumer debt falls in the range of the $40^{\text {th }}-60^{\text {th }}$ percentile of the overall distribution for consumers to be eligible for the matching. As can readily be seen in the figures, we have ample common support for the two distributions of fitted probabilities, meaning that for most of the boom county consumers in this particular slice of the predicted total debt distribution, there exists a counterpart actually living in a non-boom county with a similar propensity to live in a boom county. This observation is equally valid for the sample of homeowners (Figure 8a) as it is for the renter sample (Figure 8b).

In Tables 5a-c, we summarize the demographic variables in our matched sample. As we would expect, once we have matched on the consumer attributes from the probit regression (see Tables 4a-c), the average characteristics of consumers in the remaining sample look quite similar. This basic conclusion holds when we restrict our matching according to whether we 
observe a mortgage on the consumers' balance sheets (homeowners in Table 5b and renters in 5c). The main exception to this result, however, is the percent Hispanic variable. Even after controlling for observables, our matched sample consists of a higher percentage of borrowers in the boom counties that live in census tracts with relatively high Hispanic representation. ${ }^{21}$

With matches in hand we can then test for differences in deleveraging across counties and across different types of borrowers (homeowners and renters). The results of these tests are found in Table 6, where we report the difference in changes in debt levels between the matched individuals. Negative numbers mean that individuals living in boom counties reduced their debt levels more than did their matched counterparts in non-boom counties. For nonmortgage debt (the upper panel of Table 6), all statistically significant difference in differences estimates are negative, and all of these indicate economically important effects. In particular, for consumers with high levels of predicted nonmortgage debt (upper two deciles of the predicted debt distribution), we see evidence of greater nonmortgage debt deleveraging in boom counties than in non-boom counties for renters than for homeowners. We are working with log differences, so renters in boom counties with high predicted nonmortgage debt ( $80^{\text {th }}$ percentile) exhibit declines in that debt through 2011 that were 15 percentage points greater than renters in non-boom counties.

We also ran our propensity score matching routine on a more restricted sample of borrowers that are identified as having mortgages for the duration of the 2008-2011 period (homeowners) and again for borrowers who had no evidence of a mortgage during this same period (renters). These restrictions turn out to be important, as they guard against the possibility

\footnotetext{
${ }^{21}$ This is not surprising, given the prevalence of boom counties in California and other parts of the southwestern United States.
} 
of our matching a homeowner in a boom county with a renter in a non-boom county. Indeed, with these restrictions in place, we find that homeowners in the upper part of the predicted debt distribution did not reduce their nonmortgage debt differentially across counties. Only in the case of low predicted debt do we see homeowners in the boom counties reducing nonmortgage debt more than in the non-boom counties. For renters, declines in nonmortgage debt in the boom counties were more pervasive across the debt distribution, ranging from a difference of about 5 to 10 percentage points. As renters did not experience an adverse wealth shock due to the post2006 decline in house prices, this finding is consistent with deleveraging driven by a supply effect, rather than an optimal response of consumers. However, for nonmortgage debt, we see that the largest difference in terms of economic significance was amongst homeowners in the boom counties who, on average, reduced nonmortgage borrowing by nearly 40 percentage points compared to their matched counterparts living in non-boom counties.

The middle and lower panels in Table 6 repeat the difference in differences exercise for matched borrowers, but in these cases looking at changes in the debt subcategories. Here again we see that renters, or consumers without mortgages, reduced their auto debt and credit card debt significantly more in the boom counties than in the non-boom counties, even though these borrowers appear to have been unexposed to a direct decline in their wealth due to a house price shock. For consumers with mortgages there is actually evidence that homeowners in the boom counties lowered their auto and credit card debt less than did their counterparts in the non-boom counties.

The results in Table 6 suggest the possibility that renters in boom counties experienced a decline in banks' willingness or ability to lend. However, important drivers of differential changes in debt levels may be differential changes in demand conditions between 2008 and 
2011, as opposed to differential changes in the provision of credit. Hence we estimate variants of the following regression:

$$
\begin{aligned}
\Delta D_{i, 2011-2008} & =\alpha+\rho 1 B C+\rho 2 B C * \text { mort }_{i}+\rho 3 B C * \text { risk }_{i}+\rho 4 B C * \text { debt }_{i} \\
& +\Pi X_{i}+\Theta X+\xi \Delta u e+\text { rmort }_{i} * \Delta u e+\varepsilon, \quad(2)
\end{aligned}
$$

where $\Delta D_{i, 2011-2008}$ represents, for individual $i$ and for each type of debt (total nonmortgage debt and its components), the difference between the 2008.Q3 level and the 2011.Q4 level. ${ }^{22}$ The coefficients $\rho_{1}, \rho_{2}, \rho_{3}$, and $\rho_{4}$ on the indicator variable $B C$ ("boom county") are of most interest. The first is intended to measure the degree to which households in boom counties delever more than those in non-boom counties, controlling for changes in the non-house price elements of the demand for debt. The second allows us to see how that differential depends on whether the borrower is a homeowner, which we assess by whether there is a mortgage loan balance outstanding throughout the entire 2008.Q3-2011.Q4 sample period. The third allows us to see how that differential depends on the risk score of the borrower, and the fourth how it depends on the borrower's total debt in 2008.Q3.

In all of the changes in debt regressions to follow, we work with the matched sample of borrowers from the propensity score matching analysis above. That is, while we have both homeowners and renters from the two groups of counties, a homeowner only appears in the nonboom county if it is matched to another homeowner in a boom county, and similarly for renters. The controls in $X_{i}$ include, analogous to equation (1), the individual's age and risk score, and the number of credit report inquiries on the individual over the previous 12 months, all as of

\footnotetext{
${ }^{22}$ Our regression sample consists of pairs of individuals, matched on their probability of living in a boom county, within predicted 2008.Q2 debt ranges, as described in the text above.
} 
2008.Q3. In addition, $X_{i}$ includes the change in the individual's risk score between 2008 and 2011, whether the individual is a homeowner, and the individual's actual level of total debt, as of 2008.Q3.

The controls in $X$ include the same census tract level control variables as they appear in equation (1), with the exception of the unemployment rate, which, instead, enters equation (2) as a change between 2008 and 2011 and as a change in the unemployment rate interacted with the individual's homeowner status, as described above, in order to help capture any differential sensitivity between homeowners and renters to changes in local economic conditions.

The complement of the homeowner group in our debt changes regressions sample consists of borrowers who never had a mortgage at any time during the 2008.Q3-2011.Q4 period. Therefore, our debt changes regressions exclude borrowers who had a mortgage in at least one of the quarters between 2008.Q3 and 2011.Q4, but not all of the quarters. We impose this strict filter in order to maximize the probability that we are correctly identifying homeowners versus non-homeowners (renters).

Tables 7, 8, and 9 present the results for nonmortgage debt, auto debt, and credit card debt, respectively. The homeowner and renter sample filter just described precludes the investigation of changes in mortgage and home equity debt according to whether the borrower is a homeowner. Non-homeowners never have any mortgage debt during our sample period and, conceptually, at least, shouldn't have any home equity debt either.

The coefficients on each of the individual level controls are highly statistically significant. The results of the full specification in column (4) of Table 7 indicate that older individuals tended to delever more. As expected, a higher risk score in 2008 is correlated with 
less deleveraging. However, those consumers with risk scores that improved delevered more than consumers whose risk score worsened. ${ }^{23}$ Individuals with more inquiries tended to delever less, as expected. All other factors held constant, homeowners delevered less than renters. Consistent with MRS, more debt in 2008 was correlated with more deleveraging.

Regarding controls at the census tract level, individuals in census tracts with higher median income tended to delever less, as expected. A higher share of black households is associated with less delevering. We suppress reporting of the coefficients on the census tract level controls in Tables 8 and 9, but the results are qualitatively similar to those in Table 7.

Turning to our coefficients of most interest in Tables 7-9, unconditionally, we find no statistically significant association between residence in a boom county and the extent of deleveraging in nonmortgage debt or auto debt (Column (1) in Tables 7 and 8). For credit card debt, we do see a positive and statistically significant association between boom county and deleveraging, as in MRS (Column (1) in Table 9).

However, the coefficients on the boom county interaction terms in Tables 7-9 suggest that the correlation between residence in a boom county and deleveraging may depend on whether the individual is a homeowner or a renter and on their total debt or risk score in 2008. For example, focusing on the boom county interaction coefficients that are statistically significant in Table 7, being a homeowner strengthens the negative association between boom county and deleveraging in nonmortgage debt that comes merely from having a positive risk score (Column (4) in Table 7). Renters do not see this boost to the negative association between boom county and deleveraging.

\footnotetext{
${ }^{23}$ In part this may just be due to reverse causality, as those who delevered more may have improved their risk score more.
} 
While the negative association between boom county and deleveraging in nonmortgage debt that these interacted results suggest contrasts with the positive association between boom county and deleveraging that MRS found, the important point here is that the effect of residence in a boom county on any deleveraging in nonmortgage debt tends to be larger for renters than for homeowners. This is indicated by the positive coefficient on the interaction between homeowner and boom county and by the positive coefficient on the interaction between 2008 risk score and $B C$ combined with lower average risk scores for renters than homeowners (712 vs. 767, respectively, in the regression sample). Therefore, any deleveraging driven, for example, by a high level of debt in 2008, will be more strongly mitigated by residence in a boom county for homeowners than it is for renters. Given equal deleveraging in non-boom counties, then, homeowners in boom counties will delever less than renters in boom counties. This suggests that deleveraging was driven more by declines in the provision of credit than by a demand-based response to lower housing wealth.

Table 10 shows the signs and, where relevant, the relative magnitudes, of the estimated effect of $B C$ on the change in debt for homeowners and renters, taking into account the statistically significant coefficients (at a 10 percent level or better) on $B C$ and its interaction terms and the means of 2008 risk score or 2008 debt, as relevant, for homeowners and, separately, for renters, in the full regression sample. For example, the table shows that, at the sample means for 2008 risk score for homeowners and renters, the fully interacted effect of $B C$ on the change in nonmortgage debt is more positive for homeowners than for renters, as just discussed. Indeed, a renter would need to have a risk score at least 262 points higher than a homeowner to experience a more positive effect than the homeowner. 
The results for auto and credit card debt also support the view that deleveraging was more a consequence of reductions in the provision of credit than of changes in the demand for credit. For auto debt, the coefficient on the interaction between boom county and homeowner is not statistically significant. However, since homeowners have higher mean risk scores than renters, the negative effect of boom county and the change in auto debt is calculated to be more attenuated for homeowners than renters, similar to the situation with nonmortgage debt. More generally, about 57\% of the homeowners in the regression sample have high enough 2008 risk scores to experience a positive fully interacted effect of $B C$ on the change in auto debt, vs. about $41 \%$ of sample renters. Regarding credit card debt, for renters, the estimated fully interacted effect of boom county on the change in leverage always is negative, due to the negative coefficient on 2008 debt interacted with boom county. In contrast, the sizable positive coefficient on homeowner interacted with boom county is large enough to yield a positive sign at the sample mean of 2008 homeowner debt and, indeed, at virtually all sample values of 2008 homeowner debt.

We've told our story in terms of renters versus homeowners in Table 10. A broader perspective also supports the view of the relative importance of declines in the provision of credit. The marginal effects revealed by the signs of the individual coefficients on the $B C$ and its interaction terms in Tables 7-9 imply that the difference in any tendency toward deleveraging between boom counties and non-boom counties was stronger for individuals who did not own homes, had lower risk scores in 2008, or had higher debt in 2008. Taken together, these results support the view that residents of boom counties faced sharper declines in the provision of credit than did residents of non-boom counties, as revealed by financially weaker individuals seeming to take the brunt of the tighter conditions. In addition, the signs and statistical significance of the 
coefficients on homeownership, 2008 risk score, and 2008 debt by themselves are fully consistent with this view. We interpret the $B C$ and individual control results together as suggesting that financially weaker individuals faced greater cutbacks in credit everywhere, but that the difference between changes in credit conditions for financially weaker vs. stronger individuals was greatest in boom counties.

\section{Conclusion}

Previous empirical research has suggested that the tremendous blow to the housing market contributed to the sharp drop in aggregate consumer debt. We investigate whether such a link may be due more to cutbacks in the provision of credit, as the value of housing collateral fell, local economies weakened, and credit standards may have tightened, or to reduced demand for credit, due to standard wealth effects. First, using the Federal Reserve Board's Senior Loan Officer Opinion Survey, that banks did indeed tighten credit standards in boom counties more than in non-boom counties. In order to ascertain the economic importance of this finding, we use individual credit file data and find evidence suggesting that credit supply effects were important. Demand effects would work through homeowners more than renters. In our estimations, we find that, for nonmortgage debt and credit card debt, renters with low risk scores delevered more in counties with large house price declines than in counties with small house price declines. In contrast, homeowners reduced these types of debt less in counties with large house price declines than in counties with small house price declines. Our evidence supports the view that cutbacks in aggregate borrowing were due more to lender behavior than to a demand-based response to lower housing wealth. 


\section{$\underline{\text { References }}$}

Agarwal, Sumit, Chunlin Liu, and Nicholas S. Souleles (2007): "The Reaction of Consumer Spending and Debt to Tax Rebates -- Evidence from Consumer Credit Data," Journal of Political Economy, 115 (6), 986-1019.

Bhutta, Neil (2013): “Household Deleveraging: Evidence from Consumer Credit Record Data.” Working Paper.

Brown, M., Stein, S., and Zafar, B., 2013. “The Impact of Housing Markets on Consumer Debt: Credit Report Evidence from 1999-2012.

Carroll, Christopher D. (1992): "The Buffer-Stock Theory of Saving: Some Macroeconomic Evidence,” Brookings Papers on Economic Activity, 1992(2), 61-156, http://econ.jhu.edu/people/ccarroll/BufferStockBPEA.pdf

Carroll, Christopher D. (2013): "Representing Consumption and Saving Without a Representative Consumer.” Working paper.

Cohen-Cole, Ethan (2011): “Credit Card Redlining, " Review of Economics and Statistics, 93(2), 700-713.

Damar, Evren, Reint Gropp, and Adi Mordell (2012): “Banks’ Financial Distress, Lending Supply, and Consumption Expenditure,” unpublished manuscript.

Davis, Morris, and Michael Palumbo (2001): "A Primer on the Economics and Time Series Econometrics of Wealth Effects,” Finance and Economics Discussion Series 2001-09, Federal Reserve Board.

Dynan, Karen, and Wendy Edelberg (2013): “What’s Driving Deleveraging?” Working Paper.

Eggertsson, Gauti B., and Paul Krugman (2012): "Debt, Deleveraging, and the Liquidity Trap: A Fisher-Minsky-Koo Approach,” unpublished manuscript (February).

Glick, Reuven, and Kevin Lansing (2009): "U.S. Household Deleveraging and Future Consumption Growth,” Economic Letter 2009-16, Federal Reserve Bank of San Francisco.

Glick, Reuven, and Kevin Lansing (2010): “Global Household Leverage, House Prices, and Consumption,” Economic Letter 2010-01, Federal Reserve Bank of San Francisco.

Guerrieri, Veronica, and Guido Lorenzoni (2011): “Credit Crises, Precautionary Savings, and the Liquidity Trap,” unpublished manuscript (October).

Hall, Robert E. (2011): “The Long Slump,” American Economic Review, 101(2), 431-469. 
Hedberg, William, and John Krainer (2012): “Consumer Debt and the Economic Recovery.” Economic Letter 2012-25. Federal Reserve Bank of San Francisco.

Hurst, Eric, and Frank Stafford (2004): "Home is Where the Equity Is: Mortgage Refinancing and Household Consumption,” Journal of Money, Credit, and Banking, 36(6), 985-1014.

Jorda, Oscar, Moritz Schularick, and Alan M. Taylor (2011); “When Credit Bites Back:

Leverage, Business Cycles, and Crises,” Federal Reserve Bank of San Francisco Working Paper Series 2011-27.

Lee, D., and Van der Klauuw, W., 2010. “An Introduction to the FRBNY Consumer Credit Panel.” Federal Reserve Bank of New York Staff Report.

Mian, Atif, Kamalesh Rao, and Amir Sufi (2012): "Household Balance Sheets, Consumption, and the Economic Slump,” unpublished manuscript (June 1, 2012). Available at SSRN:

http://ssrn.com/abstract=1961211 or http://dx.doi.org/10.2139/ssrn.1961211

Mian, Atif, and Amir Sufi (2011): "House Prices, Home Equity-Based Borrowing, and the U.S. Household Leverage Crisis,” American Economic Review, 101, 2132-2156 or http://www.aeaweb.org/articles.php?doi=10.1275/aer.101.5.2132

Mian, Atif, and Amir Sufi (2010): “Household Leverage and the Recession of 2007 to 2009," International Monetary Fund Economic Review, 58, 74-117.

Midrigan, Vergiliu, and Thomas Philippon (2011): "Household Leverage and the Recession,” unpublished manuscript (November).

Musto, David K., and Nicholas S. Souleles (2006): “A Portfolio View of Consumer Credit,” Journal of Monetary Economics, 53(1), 59-84.

Saiz, Albert (2010): “The Geographic Determinants of Housing Supply,” Quarterly Journal of Economics, 125(3), 1253-1296.

Stango, Victor (2002): "Pricing With Consumer Switching Costs: Evidence from the Credit Card Market,” Journal of Industrial Economics, L(4), 475-492. 


\section{Table 1: Consumer Debt Summary Statistics}

All figures in nominal dollars

\begin{tabular}{l|rrr} 
& \multicolumn{3}{c}{ Full Sample } \\
\hline Total Debt & $\$ 2,114$ & $\$ 14,709$ & $\$ 79,866$ \\
Mortgage & $\$ 73,619$ & $\$ 123,573$ & $\$ 202,000$ \\
Home Equity & $\$ 14,653$ & $\$ 27,574$ & $\$ 50,000$ \\
Nonmortgage & $\$ 1,190$ & $\$ 5,827$ & $\$ 16,617$ \\
Auto & $\$ 6,677$ & $\$ 12,066$ & $\$ 19,398$ \\
Credit Card & $\$ 652$ & $\$ 2,147$ & $\$ 6,665$
\end{tabular}

\begin{tabular}{l|rrr}
\multicolumn{4}{c}{$2002 \mathrm{Q} 4$} \\
\\
\hline Total Debt & $\$ 2,029$ & $\$ 13,980$ & $\$ 66,117$ \\
Mortgage & $\$ 65,197$ & $\$ 106,000$ & $\$ 164,000$ \\
Home Equity & $\$ 12,493$ & $\$ 23,494$ & $\$ 37,553$ \\
Nonmortgage & $\$ 1,130$ & $\$ 5,591$ & $\$ 16,425$ \\
Auto & $\$ 7,005$ & $\$ 12,436$ & $\$ 19,509$ \\
Credit Card & $\$ 675$ & $\$ 2,170$ & $\$ 6,626$
\end{tabular}

\begin{tabular}{l|rrr}
\multicolumn{4}{c}{$2008 \mathrm{Q} 2$} \\
\hline Total Debt & $\$ 2,509$ & $\$ 17,273$ & $\$ 98,957$ \\
Mortgage & $\$ 86,978$ & $\$ 147,920$ & $\$ 247,729$ \\
Home Equity & $\$ 17,531$ & $\$ 31,917$ & $\$ 61,864$ \\
Nonmortgage & $\$ 1,409$ & $\$ 6,895$ & $\$ 18,894$ \\
Auto & $\$ 6,972$ & $\$ 12,849$ & $\$ 20,616$ \\
Credit Card & $\$ 723$ & $\$ 2,374$ & $\$ 7,457$
\end{tabular}

\begin{tabular}{l|rrr}
\multicolumn{4}{c}{$2011 \mathrm{Q} 4$} \\
\\
\hline Total Debt & 25th pctile & median & 75 pctile \\
Mortgage & $\$ 2,226$ & $\$ 14,368$ & $\$ 89,192$ \\
Home Equity & $\$ 87,772$ & $\$ 152,638$ & $\$ 253,418$ \\
Nonmortgage & $\$ 16,472$ & $\$ 32,549$ & $\$ 68,326$ \\
Auto & $\$ 1,379$ & $\$ 6,262$ & $\$ 17,086$ \\
Credit Card & $\$ 6,642$ & $\$ 12,050$ & $\$ 19,906$ \\
& $\$ 696$ & $\$ 2,259$ & $\$ 6,793$
\end{tabular}

Source: FRBNY Consumer Credit Panel / Equifax. All statistics conditional on Debt $>0$. 


\section{Table 2: Demographic Summary Statistics}

\begin{tabular}{l|rrrr}
\multicolumn{1}{c}{ Mean } & Std. Dev. & 25pctile & 75pctile \\
\hline Age & 48.51 & 18.36 & 34 & 61 \\
Risk Score & 693 & 106 & 616 & 783 \\
Supply Elasticity & 1.75 & 1.02 & 0.76 & 2.21 \\
Unemployment & 5.95 & 2.61 & 4.2 & 7.1 \\
Median income & $\$ 59,571$ & $\$ 28,066$ & $\$ 40,281$ & $\$ 72,806$ \\
Percent college & 29.73 & 18.81 & 15.05 & 41.08 \\
Percent black & 13.23 & 22.22 & 0.87 & 13.45 \\
Percent hispanic & 8.76 & 13.06 & 1.23 & 10.25 \\
At least one vehicle & 94.94 & 10.5 & 95.44 & 99.41 \\
Percent on food stamps & 9.87 & 9.66 & 3.02 & 13.5 \\
Percent homeowner & 65.77 & 22.15 & 51.95 & 83.44 \\
Percent households working & 78.29 & 8.02 & 74.18 & 83.84 \\
Percent married & 49.14 & 13.32 & 40.85 & 59.05 \\
High small business share & 0.24 & & &
\end{tabular}

Source: Amercian Community Survey (U.S. Census) and FRBNY

Consumer Credit Panel / Equifax. 


\section{Table 3: First Stage Regression}

This table shows the results of the regressions of the log of a consumer debt category on consumer and market-level demographics. The data are consumer-level observations from 1999.Q1 - 2008.Q2. The estimated models will then form our predictions for the demand for consumer debt in 2008.Q3.

\begin{tabular}{|c|c|c|c|c|c|c|}
\hline & $\begin{array}{c}\text { Total Debt } \\
\text { b/se }\end{array}$ & $\begin{array}{l}\text { Mortgage } \\
\text { b/se }\end{array}$ & $\begin{array}{c}\text { Home Equity } \\
\text { b/se }\end{array}$ & $\begin{array}{c}\text { Nonmortgage } \\
\text { b/se }\end{array}$ & $\begin{array}{l}\text { Auto } \\
\text { b/se }\end{array}$ & $\begin{array}{c}\text { Credit Card } \\
\text { b/se }\end{array}$ \\
\hline Supply elasticity & $\begin{array}{l}-0.000 \\
(0.002)\end{array}$ & $\begin{array}{c}0.008 * * * \\
(0.002)\end{array}$ & $\begin{array}{c}-0.022^{* * *} \\
(0.001)\end{array}$ & $\begin{array}{c}0.001 \\
(0.001)\end{array}$ & $\begin{array}{c}0.014^{* * *} \\
(0.002)\end{array}$ & $\begin{array}{c}-0.035^{* * *} \\
(0.001)\end{array}$ \\
\hline Missing elasticity & $\begin{array}{l}-0.012 * \\
(0.005)\end{array}$ & $\begin{array}{c}-0.054^{* * *} \\
(0.006)\end{array}$ & $\begin{array}{c}-0.157 * * * \\
(0.004)\end{array}$ & $\begin{array}{c}-0.024 * * * \\
(0.005)\end{array}$ & $\begin{array}{c}-0.108^{* * *} \\
(0.006)\end{array}$ & $\begin{array}{c}-0.047 * * * \\
(0.005)\end{array}$ \\
\hline Past 12 month Inquiries & $\begin{array}{c}0.336^{* * *} \\
(0.001)\end{array}$ & $\begin{array}{c}0.185^{* * * *} \\
(0.001)\end{array}$ & $\begin{array}{c}0.100 * * * \\
(0.001)\end{array}$ & $\begin{array}{c}0.320^{* * *} \\
(0.001)\end{array}$ & $\begin{array}{c}0.346^{* * *} \\
(0.001)\end{array}$ & $\begin{array}{c}0.204^{* * * *} \\
(0.001)\end{array}$ \\
\hline Unemployment & $\begin{array}{c}0.018 * * * \\
(0.003)\end{array}$ & $\begin{array}{c}-0.022 * * * \\
(0.003)\end{array}$ & $\begin{array}{c}0.048^{* * *} \\
(0.002)\end{array}$ & $\begin{array}{c}0.039 * * * \\
(0.003)\end{array}$ & $\begin{array}{c}0.041^{* * *} \\
(0.003)\end{array}$ & $\begin{array}{c}0.044^{* * *} \\
(0.003)\end{array}$ \\
\hline Median income & $\begin{array}{c}-4.661^{* * *} \\
(0.164)\end{array}$ & $\begin{array}{c}-14.714^{* * *} \\
(0.199)\end{array}$ & $\begin{array}{c}-2.009 * * * \\
(0.140)\end{array}$ & $\begin{array}{l}-0.180 \\
(0.161)\end{array}$ & $\begin{array}{c}3.053^{* * *} \\
(0.181)\end{array}$ & $\begin{array}{c}-1.133^{* * *} \\
(0.161)\end{array}$ \\
\hline Percent college & $\begin{array}{c}0.016^{* * * *} \\
(0.000)\end{array}$ & $\begin{array}{c}0.023^{* * *} \\
(0.000)\end{array}$ & $\begin{array}{c}0.001^{* * *} \\
(0.000)\end{array}$ & $\begin{array}{c}0.018^{* * *} \\
(0.000)\end{array}$ & $\begin{array}{c}0.003^{* * *} \\
(0.000)\end{array}$ & $\begin{array}{c}0.029 * * * \\
(0.000)\end{array}$ \\
\hline Percent black & $\begin{array}{c}-0.006^{* * *} \\
(0.000)\end{array}$ & $\begin{array}{c}-0.002 * * * \\
(0.000)\end{array}$ & $\begin{array}{c}-0.001^{* * *} \\
(0.000)\end{array}$ & $\begin{array}{c}-0.003^{* * *} \\
(0.000)\end{array}$ & $\begin{array}{c}0.003^{* * *} \\
(0.000)\end{array}$ & $\begin{array}{c}-0.006^{* * * *} \\
(0.000)\end{array}$ \\
\hline Percent hispanic & $\begin{array}{c}0.003^{* * *} \\
(0.000)\end{array}$ & $\begin{array}{c}0.016^{* * * *} \\
(0.000)\end{array}$ & $\begin{array}{c}-0.008^{* * *} \\
(0.000)\end{array}$ & $\begin{array}{c}0.002^{* * *} \\
(0.000)\end{array}$ & $\begin{array}{c}0.012^{* * *} \\
(0.000)\end{array}$ & $\begin{array}{c}-0.003^{* * *} \\
(0.000)\end{array}$ \\
\hline High small business share & $\begin{array}{c}-0.086^{* * *} \\
(0.015)\end{array}$ & $\begin{array}{c}-0.131^{* * *} \\
(0.018)\end{array}$ & $\begin{array}{c}-0.167^{* * *} \\
(0.013)\end{array}$ & $\begin{array}{l}-0.015 \\
(0.015)\end{array}$ & $\begin{array}{c}-0.398^{* * *} \\
(0.017)\end{array}$ & $\begin{array}{c}0.211^{* * *} \\
(0.015)\end{array}$ \\
\hline At least one vehicle & $\begin{array}{c}-0.017^{* * *} \\
(0.003)\end{array}$ & $\begin{array}{c}-0.050 * * * \\
(0.004)\end{array}$ & $\begin{array}{c}0.023^{* * *} \\
(0.003)\end{array}$ & $\begin{array}{c}-0.011^{* * *} \\
(0.003)\end{array}$ & $\begin{array}{c}-0.012^{* *} \\
(0.004)\end{array}$ & $\begin{array}{c}-0.023 * * * \\
(0.003)\end{array}$ \\
\hline Percent married & $\begin{array}{l}0.002^{* *} \\
(0.001)\end{array}$ & $\begin{array}{c}-0.020 * * * \\
(0.001)\end{array}$ & $\begin{array}{c}-0.005^{* * *} \\
(0.001)\end{array}$ & $\begin{array}{c}0.008^{* * *} \\
(0.001)\end{array}$ & $\begin{array}{c}0.008^{* * *} \\
(0.001)\end{array}$ & $\begin{array}{c}0.004^{* * * *} \\
(0.001)\end{array}$ \\
\hline Percent food stamps & $\begin{array}{c}-0.014^{* * *} \\
(0.001)\end{array}$ & $\begin{array}{c}0.001 \\
(0.001)\end{array}$ & $\begin{array}{c}-0.001^{* *} \\
(0.000)\end{array}$ & $\begin{array}{c}-0.023^{* * *} \\
(0.001)\end{array}$ & $\begin{array}{c}-0.017^{* * *} \\
(0.001)\end{array}$ & $\begin{array}{c}-0.024^{* * *} \\
(0.001)\end{array}$ \\
\hline Percent pop. Working & $\begin{array}{c}-0.011^{* * *} \\
(0.002)\end{array}$ & $\begin{array}{c}-0.017^{* * *} \\
(0.003)\end{array}$ & $\begin{array}{c}0.014^{* * *} \\
(0.002)\end{array}$ & $\begin{array}{l}-0.005^{*} \\
(0.002)\end{array}$ & $\begin{array}{l}-0.003 \\
(0.003)\end{array}$ & $\begin{array}{c}-0.010^{* * *} \\
(0.002)\end{array}$ \\
\hline Percent homeowner & $\begin{array}{c}0.007^{* * *} \\
(0.000)\end{array}$ & $\begin{array}{c}0.019 * * * \\
(0.001)\end{array}$ & $\begin{array}{c}0.010^{* * *} \\
(0.000)\end{array}$ & $\begin{array}{c}-0.002^{* * *} \\
(0.000)\end{array}$ & $\begin{array}{c}-0.005^{* * *} \\
(0.000)\end{array}$ & $\begin{array}{c}-0.004 * * * \\
(0.000)\end{array}$ \\
\hline Constant & $\begin{array}{c}14.861^{* * *} \\
(1.046)\end{array}$ & $\begin{array}{c}61.640^{* * *} \\
(1.272)\end{array}$ & $\begin{array}{l}2.041^{*} \\
(0.893)\end{array}$ & $\begin{array}{c}-5.269 * * * \\
(1.027)\end{array}$ & $\begin{array}{c}-31.735^{* * *} \\
(1.156)\end{array}$ & $\begin{array}{c}6.169 * * * \\
(1.028)\end{array}$ \\
\hline $\mathrm{N}$ & 6414248 & 6414248 & 6414248 & 6414248 & 6414248 & 6414248 \\
\hline $\begin{array}{l}\mathrm{R}^{2} \text { adjusted } \\
\text { log likelihood }\end{array}$ & $\begin{array}{c}0.211 \\
-1.739 e+07\end{array}$ & $\begin{array}{c}0.171 \\
-1.864 \mathrm{e}+07\end{array}$ & $\begin{array}{c}0.057 \\
-1.638 \mathrm{e}+07\end{array}$ & $\begin{array}{c}0.160 \\
-1.727 \mathrm{e}+07\end{array}$ & $\begin{array}{c}0.103 \\
-1.803 e+07\end{array}$ & $\begin{array}{c}0.121 \\
-1.728 \mathrm{e}+07\end{array}$ \\
\hline
\end{tabular}

Source: FRBNY Consumer Credit Panel / Equifax. 


\section{Table 4}

\section{Probability of Living in High Appreciation County}

This table presents the results from the probit model that forms the basis for the propensity-score matching routine. The dependent variable is the binary variable taking value of 1 if a consumer lives in a high appreciation county during 2008.Q3 - 2011.Q4, and 0 otherwise. Among the covariates, inquiries, age, and risk score are observed at the individual level. All other controls are observed at the county or census tract level.

\begin{tabular}{|c|c|c|c|}
\hline & $\begin{array}{c}\text { All Consumers } \\
\text { b/se }\end{array}$ & $\begin{array}{c}\text { Consumers with } \\
\text { Mortgages } \\
\text { b/se }\end{array}$ & $\begin{array}{c}\text { Consumers } \\
\text { without Mortgages } \\
\text { b/se }\end{array}$ \\
\hline Inquiries (trailing 12-month) & $\begin{array}{c}0.025 * * * \\
(0.002)\end{array}$ & $\begin{array}{c}0.053 * * * \\
(0.006)\end{array}$ & $\begin{array}{c}0.022 * * * \\
(0.003)\end{array}$ \\
\hline Age & $\begin{array}{c}0.000 \\
(0.000)\end{array}$ & $\begin{array}{c}0.004^{* * *} \\
(0.001)\end{array}$ & $\begin{array}{l}-0.001 \\
(0.000)\end{array}$ \\
\hline Risk score & $\begin{array}{c}0.000^{* * *} \\
(0.000)\end{array}$ & $\begin{array}{c}0.002^{* * *} \\
(0.000)\end{array}$ & $\begin{array}{c}0.000 * * * \\
(0.000)\end{array}$ \\
\hline County Unemployment & $\begin{array}{c}-0.117^{* * *} \\
(0.003)\end{array}$ & $\begin{array}{c}-0.193^{* * *} \\
(0.007)\end{array}$ & $\begin{array}{c}-0.124 * * * \\
(0.004)\end{array}$ \\
\hline Percent black & $\begin{array}{c}0.008 * * * \\
(0.000)\end{array}$ & $\begin{array}{c}0.010 * * * \\
(0.001)\end{array}$ & $\begin{array}{c}0.008 * * * \\
(0.000)\end{array}$ \\
\hline Percent hispanic & $\begin{array}{c}0.074^{* * *} \\
(0.001)\end{array}$ & $\begin{array}{c}0.099 * * * \\
(0.002)\end{array}$ & $\begin{array}{c}0.073^{* * *} \\
(0.001)\end{array}$ \\
\hline High Small Business Percent & $\begin{array}{c}1.632 * * * \\
(0.037)\end{array}$ & $\begin{array}{c}1.130 * * * \\
(0.091)\end{array}$ & $\begin{array}{c}1.630 * * * \\
(0.052)\end{array}$ \\
\hline Percent one vehicle & $\begin{array}{c}-0.058^{* * *} \\
(0.001)\end{array}$ & $\begin{array}{c}-0.044^{* * *} \\
(0.003)\end{array}$ & $\begin{array}{c}-0.060 * * * \\
(0.001)\end{array}$ \\
\hline Percent married & $\begin{array}{l}-0.000 \\
(0.001)\end{array}$ & $\begin{array}{c}-0.015^{* * *} \\
(0.002)\end{array}$ & $\begin{array}{l}0.002 * \\
(0.001)\end{array}$ \\
\hline Percent food stamps & $\begin{array}{c}-0.094^{* * *} \\
(0.001)\end{array}$ & $\begin{array}{c}-0.107^{* * *} \\
(0.003)\end{array}$ & $\begin{array}{c}-0.094 * * * \\
(0.001)\end{array}$ \\
\hline Percent working & $\begin{array}{c}-0.053^{* * *} \\
(0.001)\end{array}$ & $\begin{array}{c}-0.073 * * * \\
(0.002)\end{array}$ & $\begin{array}{c}-0.053^{* * *} \\
(0.001)\end{array}$ \\
\hline Percent homeowners & $\begin{array}{c}-0.008 * * * \\
(0.000)\end{array}$ & $\begin{array}{c}-0.005^{* * *} \\
(0.001)\end{array}$ & $\begin{array}{c}-0.008 * * * \\
(0.000)\end{array}$ \\
\hline Constant & $\begin{array}{c}10.990 * * * \\
(0.113)\end{array}$ & $\begin{array}{c}10.718^{* * *} \\
(0.390)\end{array}$ & $\begin{array}{c}11.188^{* * *} \\
(0.161)\end{array}$ \\
\hline Observations & 145,535 & 21,478 & 72,223 \\
\hline pseudo $\mathrm{R}^{2}$ & 0.324 & 0.328 & 0.327 \\
\hline Log likelihood & $-62,134.87$ & $-9,377.75$ & $-30,847.44$ \\
\hline
\end{tabular}

Source: FRBNY Consumer Credit Panel / Equifax. Data from 2008.Q2. Consumers living in high appreciation or low appreciation counties. High appreciation defined as belonging to 9th or 10th decile of county 2001-2006 house price appreciation. 


\section{Table 5a: Matched Sample 2008 County Demographics All Consumers}

This table presents the summary statistics of the matched sample, using all types of consumers. Consumers in high appreciation counties are matched to consumers in low appreciation counties using the probit specifications reported in Table 4 column 1.

\begin{tabular}{rrrr}
\multicolumn{2}{l}{ Low Appreciation } & \multicolumn{2}{c}{ High Appreciation } \\
Mean & Std. Dev. & Mean & Std. Dev. \\
727.81 & 89.21 & 722.74 & 89.64 \\
1.22 & 1.92 & 1.25 & 1.91 \\
4600.99 & 1872.94 & 5125.9 & 2235.31 \\
38.64 & 6.39 & 37.96 & 7.56 \\
97.01 & 5.06 & 93.62 & 12.32 \\
51.22 & 14.56 & 48.81 & 12.32 \\
66.43 & 8.22 & 65.41 & 8.92 \\
10.9 & 0.44 & 10.99 & 0.44 \\
7.71 & 7.94 & 8.11 & 8.47 \\
33.74 & 19.56 & 30.52 & 18.62 \\
5.01 & 8.24 & 13.46 & 15.18 \\
12.06 & 20.62 & 12.16 & 20.54 \\
15,795 & & 75,016 &
\end{tabular}

Source: FRBNY Consumer Credit Panel / Equifax. 


\section{Table 5b: Matched Sample 2008 County Demographics Consumers with mortgages}

This table presents the summary statistics of the matched sample, using all types of consumers. Consumers in high appreciation counties are matched to consumers in low appreciation counties using the probit specifications reported in Table 4 column 2.

\begin{tabular}{|c|c|c|c|}
\hline \multicolumn{2}{|c|}{ Low Appreciation } & \multicolumn{2}{|c|}{ High Appreciation } \\
\hline Mean & Std. Dev. & Mean & Std. Dev. \\
\hline 764.59 & 62.03 & 768.13 & 61.84 \\
\hline 1.37 & 1.86 & 1.41 & 1.82 \\
\hline $4,868.32$ & $1,987.62$ & $5,323.97$ & $2,352.20$ \\
\hline 39.4 & 5.69 & 38.94 & 6.74 \\
\hline 98.03 & 3.55 & 96.74 & 7.01 \\
\hline 55.62 & 12.3 & 53.09 & 10.86 \\
\hline 67.46 & 7.66 & 66.31 & 7.85 \\
\hline 11.04 & 0.39 & 11.15 & 0.4 \\
\hline 5.53 & 5.72 & 5.79 & 6.16 \\
\hline 37.14 & 18.61 & 34.55 & 18.87 \\
\hline 4.2 & 6.45 & 11.65 & 13.24 \\
\hline 8.09 & 15.15 & 8.49 & 15.37 \\
\hline 3,033 & & 13,871 & \\
\hline
\end{tabular}

Source: FRBNY Consumer Credit Panel / Equifax. 


\section{Table 5c: Matched Sample 2008 County Demographics Consumers without mortgages}

This table presents the summary statistics of the matched sample, using all types of consumers. Consumers in high appreciation counties are matched to consumers in low appreciation counties using the probit specifications reported in Table 4 column 3.

Low Appreciation

Mean Std. Dev.

Risk Score

Credit Inquiries (trailing 12-month)

County Population

Median Age

Percent Population w/ at least one vehicle

Percent Married

Percent in labor force

Median Income (log)

Percent on food stamps

Percent college education

Percent hispanic

Percent black

Observations

$\begin{array}{rr}715.82 & 94.75 \\ 1.14 & 1.88 \\ 4,493.67 & 1,839.96 \\ 38.53 & 6.49 \\ 96.66 & 5.44 \\ 49.7 & 14.69 \\ 65.86 & 8.37 \\ 10.85 & 0.44 \\ 8.59 & 8.55 \\ 31.81 & 19.39 \\ 5.29 & 8.71 \\ 13.84 & 22.7 \\ 9,925 & \end{array}$

High Appreciation Mean Std. Dev.

$\begin{array}{rr}710.13 & 93 \\ 1.17 & 1.9 \\ 5,070.41 & 2,202.19 \\ 37.72 & 7.71 \\ 92.71 & 13.33 \\ 47.53 & 12.3 \\ 65.07 & 9.12 \\ 10.94 & 0.44 \\ 8.88 & 8.97 \\ 28.92 & 18.1 \\ 14.07 & 15.69 \\ 13.43 & 22.01 \\ 48,286 & \end{array}$

Source: FRBNY Consumer Credit Panel / Equifax. 


\section{Table 6: Propensity Score Matching Results}

This table presents the results of a differences in mean t-test between changes in a debt from 2008.Q3 - 2011.Q4 among consumers living in high appreciation counties and consumers living in low appreciation counties. All results are based on a sample of matched consumers as described in the propensity-score matching method. A negative difference in mean debt change signifies that that declined more in the high appreciation counties than in low appreciation counties.

\section{Total Nonmortgage Debt}

percentile of total predicted debt 2008.Q2

\begin{tabular}{l|ccc}
\hline All consumers & $-.113^{* *}$ & -.033 & $-.151^{* * *}$ \\
& $(.061)$ & $(.034)$ & $(.023)$ \\
& & & \\
Consumers with mortgages & $-.384^{* * *}$ & .075 & -.007 \\
& $(.131)$ & $(.069)$ & $(.052)$ \\
& & & \\
Consumers without mortgages & $-.100^{*}$ & -.058 & $-.079 * * *$ \\
& $(.075)$ & $(.045)$ & $(.029)$
\end{tabular}

\section{Auto Debt}

percentile of total predicted debt 2008.Q2 20th pctile 40th-60th ] 80th pctile

\begin{tabular}{|c|c|c|c|}
\hline All consumers & $\begin{array}{l}-.007 \\
(.051)\end{array}$ & $\begin{array}{c}-.363^{* * *} \\
(.071)\end{array}$ & $\begin{array}{c}.419 * * * \\
(.029)\end{array}$ \\
\hline Consumers with mortgages & $\begin{array}{l}-.073 \\
(.119)\end{array}$ & $\begin{array}{l}.236^{* *} \\
(.115)\end{array}$ & $\begin{array}{c}.265 * * * \\
(.055)\end{array}$ \\
\hline Consumers without mortgages & $\begin{array}{c}-.125^{*} \\
(.063)\end{array}$ & $\begin{array}{c}-.154^{* *} \\
(.070)\end{array}$ & $\begin{array}{c}-.444 * * \\
(.077)\end{array}$ \\
\hline
\end{tabular}

Note: consumers with post-2008 default history or bankruptcy excluded.

Differences in change in debt across high and low appreciation counties between 2008-Q3 - 2011.Q4

\section{Credit Card Debt}

percentile of total predicted debt 2008.Q2

\begin{tabular}{l|ccc}
\hline All consumers & -.036 & $-.142^{* * *}$ & $.208^{* * *}$ \\
& $(.052)$ & $(.054)$ & $(.022)$ \\
& & & \\
Consumers with mortgages & -.073 & $.236^{* *}$ & $.265^{* * *}$ \\
& $(.119)$ & $(.115)$ & $(.055)$ \\
& & & \\
Consumers without mortgages & $-.125^{*}$ & $-.154^{* *}$ & $.050^{*}$ \\
& $(.063)$ & $(.070)$ & $(.028)$
\end{tabular}

Source: FRBNY Consuer Credit Panel / Equifax. 


\section{Table 7: Change in Nonmortgage Debt}

This table presents the debt change regressions for consumers present in the sample from 2008.Q3-2011.Q4. All consumers in the high appreciation counties have been matched to to consumers in low appreciation counties as reported in Table 4.

\begin{tabular}{|c|c|c|c|c|}
\hline & (1) & $(2)$ & (3) & (4) \\
\hline Boom county & $\begin{array}{c}0.026 \\
(0.034)\end{array}$ & $\begin{array}{l}-0.028 \\
(0.043)\end{array}$ & $\begin{array}{c}-0.637 * \\
(0.303)\end{array}$ & $\begin{array}{l}-0.582 \\
(0.299)\end{array}$ \\
\hline Boom county x homeowner & & $\begin{array}{c}0.210 * * \\
(0.079)\end{array}$ & $\begin{array}{l}0.175 * \\
(0.079)\end{array}$ & $\begin{array}{c}0.261 * * \\
(0.091)\end{array}$ \\
\hline Boom county x 2008.Q3 risk score & & & $\begin{array}{l}0.001 * \\
(0.000)\end{array}$ & $\begin{array}{l}0.001 * \\
(0.000)\end{array}$ \\
\hline Boom county x 2008.Q3 total debt & & & & $\begin{array}{l}-0.015 \\
(0.009)\end{array}$ \\
\hline 2008.Q3 age & $\begin{array}{c}-0.024 * * * \\
(0.001)\end{array}$ & $\begin{array}{c}-0.024 * * * \\
(0.001)\end{array}$ & $\begin{array}{c}-0.024^{* * *} \\
(0.001)\end{array}$ & $\begin{array}{c}-0.024^{* * *} \\
(0.001)\end{array}$ \\
\hline 2008.Q3 risk score & $\begin{array}{c}0.003^{* * *} \\
(0.000)\end{array}$ & $\begin{array}{c}0.003 * * * \\
(0.000)\end{array}$ & $\begin{array}{c}0.002 * * * \\
(0.000)\end{array}$ & $\begin{array}{c}0.002 * * * \\
(0.000)\end{array}$ \\
\hline Change risk score & $\begin{array}{c}-0.007 * * * \\
(0.000)\end{array}$ & $\begin{array}{c}-0.007 * * * \\
(0.000)\end{array}$ & $\begin{array}{c}-0.007^{* * *} \\
(0.000)\end{array}$ & $\begin{array}{c}-0.007 * * * \\
(0.000)\end{array}$ \\
\hline Inquiries (trailing 12-month) & $\begin{array}{c}0.087 * * * \\
(0.008)\end{array}$ & $\begin{array}{c}0.087 * * * \\
(0.008)\end{array}$ & $\begin{array}{c}0.087 * * * \\
(0.008)\end{array}$ & $\begin{array}{c}0.087 * * * \\
(0.008)\end{array}$ \\
\hline Homeowner (2008.Q3 - 2011.Q4) & $\begin{array}{c}1.179 * * * \\
(0.077)\end{array}$ & $\begin{array}{c}1.073 * * * \\
(0.079)\end{array}$ & $\begin{array}{c}1.099 * * * \\
(0.078)\end{array}$ & $\begin{array}{c}1.029 * * * \\
(0.082)\end{array}$ \\
\hline 2008.Q3 total debt & $\begin{array}{c}-0.277 * * * \\
(0.005)\end{array}$ & $\begin{array}{c}-0.277 * * * \\
(0.005)\end{array}$ & $\begin{array}{c}-0.277^{* * *} \\
(0.005)\end{array}$ & $\begin{array}{c}-0.264 * * * \\
(0.008)\end{array}$ \\
\hline Median income & $\begin{array}{c}0.168 * * \\
(0.061)\end{array}$ & $\begin{array}{c}0.165 * * \\
(0.061)\end{array}$ & $\begin{array}{c}0.164^{* *} \\
(0.061)\end{array}$ & $\begin{array}{c}0.165 * * \\
(0.061)\end{array}$ \\
\hline Percent college & $\begin{array}{c}0.001 \\
(0.001)\end{array}$ & $\begin{array}{c}0.001 \\
(0.001)\end{array}$ & $\begin{array}{c}0.001 \\
(0.001)\end{array}$ & $\begin{array}{c}0.001 \\
(0.001)\end{array}$ \\
\hline Percent hispanic & $\begin{array}{l}-0.002 \\
(0.002)\end{array}$ & $\begin{array}{l}-0.002 \\
(0.002)\end{array}$ & $\begin{array}{l}-0.002 \\
(0.002)\end{array}$ & $\begin{array}{l}-0.002 \\
(0.002)\end{array}$ \\
\hline Percent black & $\begin{array}{c}0.002 * * \\
(0.001)\end{array}$ & $\begin{array}{c}0.002 * * \\
(0.001)\end{array}$ & $\begin{array}{c}0.002 * * \\
(0.001)\end{array}$ & $\begin{array}{c}0.002 * * \\
(0.001)\end{array}$ \\
\hline High small business pct & $\begin{array}{l}-0.075 \\
(0.111)\end{array}$ & $\begin{array}{c}-0.072 \\
(0.111)\end{array}$ & $\begin{array}{l}-0.066 \\
(0.112)\end{array}$ & $\begin{array}{l}-0.068 \\
(0.112)\end{array}$ \\
\hline Percent 1 vehicle & $\begin{array}{c}-0.003^{* *} \\
(0.001)\end{array}$ & $\begin{array}{c}-0.004^{* *} \\
(0.001)\end{array}$ & $\begin{array}{c}-0.004^{* *} \\
(0.001)\end{array}$ & $\begin{array}{c}-0.004^{* *} \\
(0.001)\end{array}$ \\
\hline Percent married & $\begin{array}{l}0.003^{*} \\
(0.001)\end{array}$ & $\begin{array}{l}0.003 * \\
(0.001)\end{array}$ & $\begin{array}{l}0.003^{*} \\
(0.001)\end{array}$ & $\begin{array}{l}0.003 * \\
(0.001)\end{array}$ \\
\hline Percent foodstamps & $\begin{array}{c}0.002 \\
(0.003)\end{array}$ & $\begin{array}{c}0.002 \\
(0.003)\end{array}$ & $\begin{array}{c}0.002 \\
(0.003)\end{array}$ & $\begin{array}{c}0.002 \\
(0.003)\end{array}$ \\
\hline Percent working & $\begin{array}{c}0.002 \\
(0.002)\end{array}$ & $\begin{array}{c}0.002 \\
(0.002)\end{array}$ & $\begin{array}{c}0.002 \\
(0.002)\end{array}$ & $\begin{array}{c}0.002 \\
(0.002)\end{array}$ \\
\hline Percent homeowner & $\begin{array}{c}0.000 \\
(0.001)\end{array}$ & $\begin{array}{c}0.000 \\
(0.001)\end{array}$ & $\begin{array}{c}0.000 \\
(0.001)\end{array}$ & $\begin{array}{c}0.000 \\
(0.001)\end{array}$ \\
\hline Change unemployment & $\begin{array}{c}-0.029 * \\
(0.014)\end{array}$ & $\begin{array}{l}-0.024 \\
(0.014)\end{array}$ & $\begin{array}{l}-0.024 \\
(0.014)\end{array}$ & $\begin{array}{l}-0.024 \\
(0.014)\end{array}$ \\
\hline Chg unemployment $\mathrm{x}$ homeowner & $\begin{array}{l}0.052 * \\
(0.022)\end{array}$ & $\begin{array}{c}0.029 \\
(0.024)\end{array}$ & $\begin{array}{c}0.029 \\
(0.024)\end{array}$ & $\begin{array}{c}0.029 \\
(0.024)\end{array}$ \\
\hline Constant & $\begin{array}{c}-1.269 * \\
(0.581)\end{array}$ & $\begin{array}{c}-1.203^{*} \\
(0.585)\end{array}$ & $\begin{array}{l}-0.697 \\
(0.655)\end{array}$ & $\begin{array}{l}-0.745 \\
(0.653)\end{array}$ \\
\hline Observations & 67,951 & 67,951 & 67,951 & 67,951 \\
\hline $\begin{array}{l}\mathrm{R}^{2} \text { adjusted } \\
\text { Log likelihood }\end{array}$ & $\begin{array}{c}0.114 \\
-171028\end{array}$ & $\begin{array}{c}0.114 \\
-171024\end{array}$ & $\begin{array}{c}0.114 \\
-171021\end{array}$ & $\begin{array}{c}0.114 \\
-171019\end{array}$ \\
\hline
\end{tabular}

Source: FRBNY Consumer Credit Panel / Equifax. 


\section{Table 8: Change in Auto Debt}

This table presents the debt change regressions for consumers present in the sample from 2008.Q3-2011.Q4. All consumers in the high appreciation counties have been matched to to consumers in low appreciation counties as reported in Table 4.

\begin{tabular}{|c|c|c|c|c|}
\hline & (1) & $(2)$ & (3) & (4) \\
\hline \multirow[t]{2}{*}{ Boom county } & -0.051 & -0.075 & $-0.753 *$ & $-0.769 *$ \\
\hline & $(0.057)$ & $(0.058)$ & $(0.328)$ & $(0.329)$ \\
\hline \multirow[t]{2}{*}{ Boom county $\mathrm{x}$ homeowner } & & 0.094 & 0.055 & 0.030 \\
\hline & & $(0.108)$ & $(0.109)$ & $(0.140)$ \\
\hline \multirow[t]{2}{*}{ Boom county x 2008.Q3 risk score } & & & $0.001 *$ & $0.001 *$ \\
\hline & & & $(0.000)$ & $(0.000)$ \\
\hline \multirow[t]{2}{*}{ Boom county x 2008.Q3 total debt } & & & & 0.004 \\
\hline & & & & $(0.012)$ \\
\hline \multirow[t]{2}{*}{ 2008.Q3 age } & $-0.013 * * *$ & $-0.013 * * *$ & $-0.013 * * *$ & $-0.013 * * *$ \\
\hline & $(0.001)$ & $(0.001)$ & $(0.001)$ & $(0.001)$ \\
\hline \multirow[t]{2}{*}{ 2008.Q3 risk score } & $0.001 * * *$ & $0.001 * * *$ & 0.000 & 0.000 \\
\hline & $(0.000)$ & $(0.000)$ & $(0.000)$ & $(0.000)$ \\
\hline \multirow[t]{2}{*}{ Change risk score } & $-0.001 * * *$ & $-0.001 * * *$ & $-0.001 * * *$ & $-0.001 * * *$ \\
\hline & $(0.000)$ & $(0.000)$ & $(0.000)$ & $(0.000)$ \\
\hline \multirow[t]{2}{*}{ Inquiries (trailing 12-month) } & $0.049 * * *$ & $0.049 * * *$ & $0.049 * * *$ & $0.049 * * *$ \\
\hline & $(0.011)$ & $(0.011)$ & $(0.011)$ & $(0.011)$ \\
\hline \multirow[t]{2}{*}{ Homeowner (2008.Q3 - 2011.Q4) } & $0.644 * * *$ & $0.596 * * *$ & $0.626 * * *$ & $0.646^{* * *}$ \\
\hline & $(0.114)$ & $(0.125)$ & $(0.125)$ & $(0.137)$ \\
\hline \multirow[t]{2}{*}{ 2008.Q3 total debt } & $-0.179 * * *$ & $-0.179 * * *$ & $-0.179 * * *$ & $-0.182 * * *$ \\
\hline & $(0.007)$ & $(0.007)$ & $(0.007)$ & $(0.010)$ \\
\hline Census tract level controls? & Yes & Yes & Yes & Yes \\
\hline \multirow[t]{2}{*}{ Constant } & -0.749 & -0.720 & -0.157 & -0.143 \\
\hline & $(0.872)$ & $(0.875)$ & $(0.918)$ & $(0.916)$ \\
\hline Observations & 67,951 & 67,951 & 67,951 & 67,951 \\
\hline $\mathrm{R}^{2}$ adjusted & 0.023 & 0.023 & 0.023 & 0.023 \\
\hline Log likelihood & $-194,075$ & $-194,075$ & $-194,073$ & $-194,073$ \\
\hline
\end{tabular}

Source: FRBNY Consumer Credit Panel / Equifax 


\section{Table 9: Change in Credit Card Debt}

This table presents the debt change regressions for consumers present in the sample from 2008.Q3-2011.Q4. All consumers in the high appreciation counties have been matched to to consumers in low appreciation counties as reported in Table 4.

\begin{tabular}{|c|c|c|c|c|}
\hline & (1) & $(2)$ & (3) & (4) \\
\hline \multirow[t]{2}{*}{ Boom county } & $0.090 * *$ & 0.046 & -0.207 & -0.143 \\
\hline & $(0.029)$ & $(0.035)$ & $(0.218)$ & $(0.216)$ \\
\hline \multirow[t]{2}{*}{ Boom county x homeowner } & & $0.172 *$ & $0.158 *$ & $0.257 * *$ \\
\hline & & $(0.077)$ & $(0.079)$ & $(0.090)$ \\
\hline \multirow[t]{2}{*}{ Boom county x 2008.Q3 risk score } & & & 0.000 & 0.000 \\
\hline & & & $(0.000)$ & $(0.000)$ \\
\hline \multirow[t]{2}{*}{ Boom county x 2008.Q3 total debt } & & & & $-0.018 *$ \\
\hline & & & & $(0.007)$ \\
\hline \multirow[t]{2}{*}{ 2008.Q3 age } & $-0.021 * * *$ & $-0.021 * * *$ & $-0.021 * * *$ & $-0.021 * * *$ \\
\hline & $(0.001)$ & $(0.001)$ & $(0.001)$ & $(0.001)$ \\
\hline \multirow[t]{2}{*}{ 2008.Q3 risk score } & $0.003 * * *$ & $0.003^{* * *}$ & $0.003 * * *$ & $0.002 * * *$ \\
\hline & $(0.000)$ & $(0.000)$ & $(0.000)$ & $(0.000)$ \\
\hline \multirow[t]{2}{*}{ Change risk score } & $-0.008 * * *$ & $-0.008 * * *$ & $-0.008 * * *$ & $-0.008 * * *$ \\
\hline & $(0.000)$ & $(0.000)$ & $(0.000)$ & $(0.000)$ \\
\hline \multirow[t]{2}{*}{ Inquiries (trailing 12-month) } & $0.085^{* * *}$ & $0.085^{* * *}$ & $0.085 * * *$ & $0.085 * * *$ \\
\hline & $(0.008)$ & $(0.008)$ & $(0.008)$ & $(0.008)$ \\
\hline \multirow[t]{2}{*}{ Homeowner (2008.Q3 - 2011.Q4) } & $0.651^{* * *}$ & $0.563 * * *$ & $0.574 * * *$ & $0.493 * * *$ \\
\hline & $(0.070)$ & $(0.075)$ & $(0.076)$ & $(0.078)$ \\
\hline \multirow[t]{2}{*}{ 2008.Q3 total debt } & $-0.163 * * *$ & $-0.163 * * *$ & $-0.163 * * *$ & $-0.148 * * *$ \\
\hline & $(0.004)$ & $(0.004)$ & $(0.004)$ & $(0.006)$ \\
\hline Census tract level controls? & Yes & Yes & Yes & Yes \\
\hline \multirow[t]{2}{*}{ Constant } & -0.313 & -0.259 & -0.049 & -0.104 \\
\hline & $(0.576)$ & $(0.574)$ & $(0.590)$ & $(0.591)$ \\
\hline Observations & 67,951 & 67,951 & 67,951 & 67,951 \\
\hline $\mathrm{R}^{2}$ adjusted & 0.071 & 0.071 & 0.071 & 0.071 \\
\hline Log likelihood & $-165,875$ & $-165,872$ & $-165,872$ & $-165,869$ \\
\hline
\end{tabular}

Source: FRBNY Consumer Credit Panel / Equifax 


\section{Table 10: Estimated Total Effect of Exposure to Boom Counties}

This table shows the signs of the estimated effect of the boom county variable on the change in consumer debt during 2008.Q3-2011.Q4. Effects were calculated based on results in column 4 of tables 7-9, respectively. The total effect is the sign of the sum of boom county + boom county $\mathrm{x}$ homeowner + boom county x 2008.Q3 risk score + boom county x 2008.Q3. Coefficients that were not statistically significant were given the value of zero.

2008.Q3 risk scores and total debt are evaluated at the sample means for that time period, for the relevant subsamples (homeowner or renter). The symbols ">>" and ">" $("<<"$ and " $<$ ") indicate relative magnitudes.

\begin{tabular}{l|ccc}
\multicolumn{1}{l}{} & Nonmortgage & Auto & Credit Card \\
\hline 2008 Homeowner & $>>0$ & $<0$ & $>0$ \\
2008 Renter & $>0$ & $<<0$ & $<0$
\end{tabular}

Source: FRBNY Consumer Credit Panel/ Equifax. 
Figure 1: Cumulative Tightening of Lending Standards in Boom and Non-boom Counties
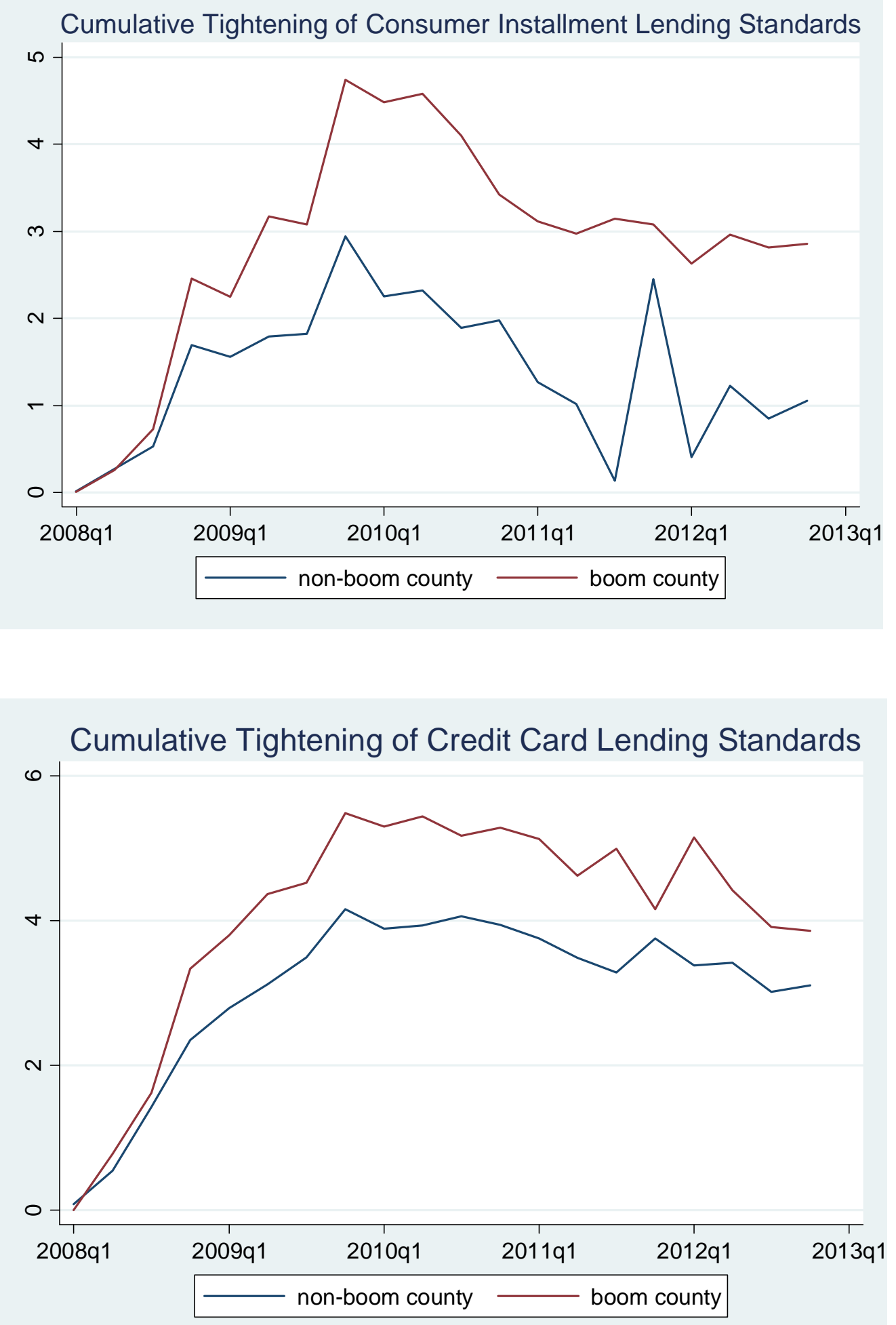

Source: Senior Loan Officer Opinion Survey and authors’ calculations (see text). 
Figure 2

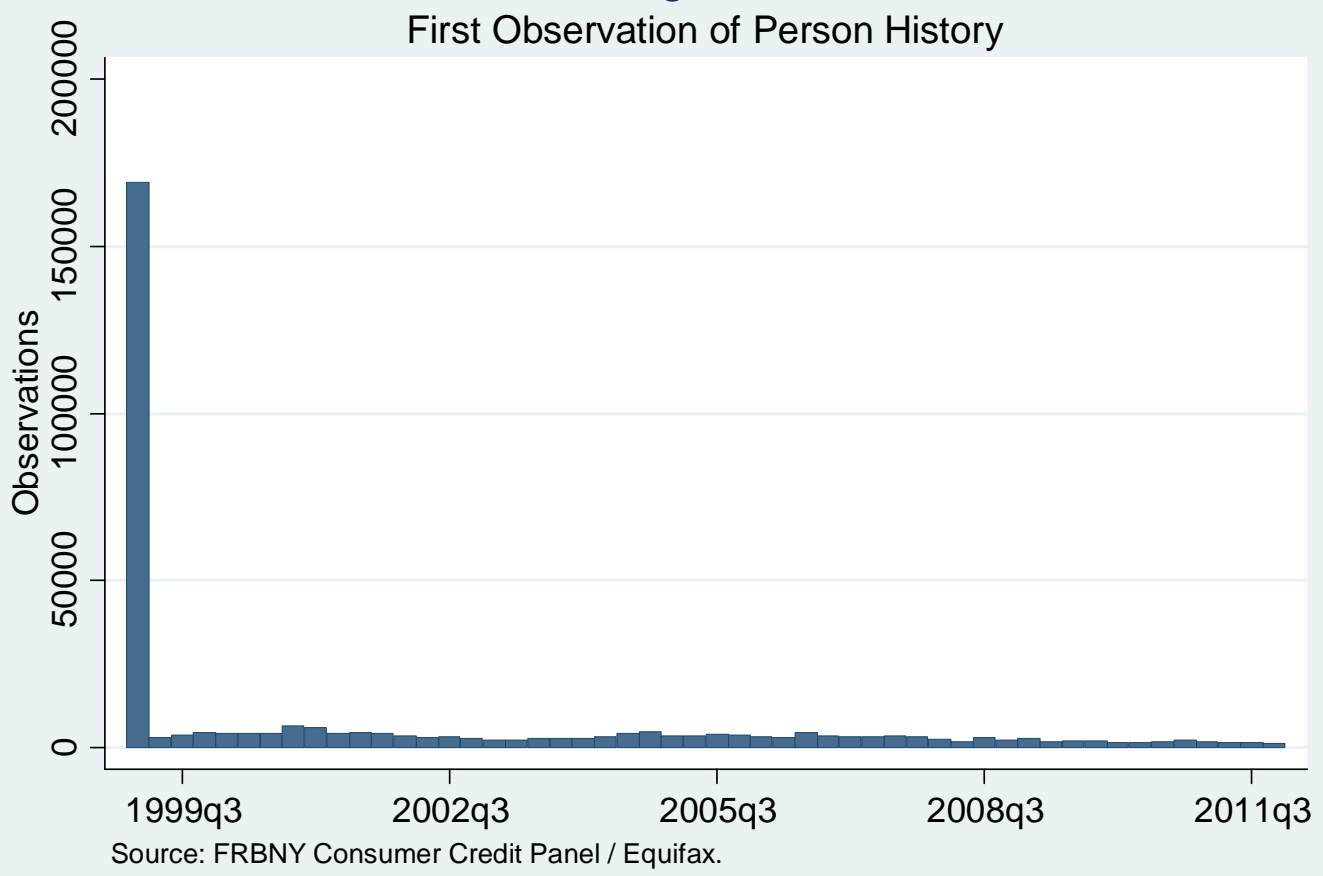

Figure 3

Last Observation of Person History

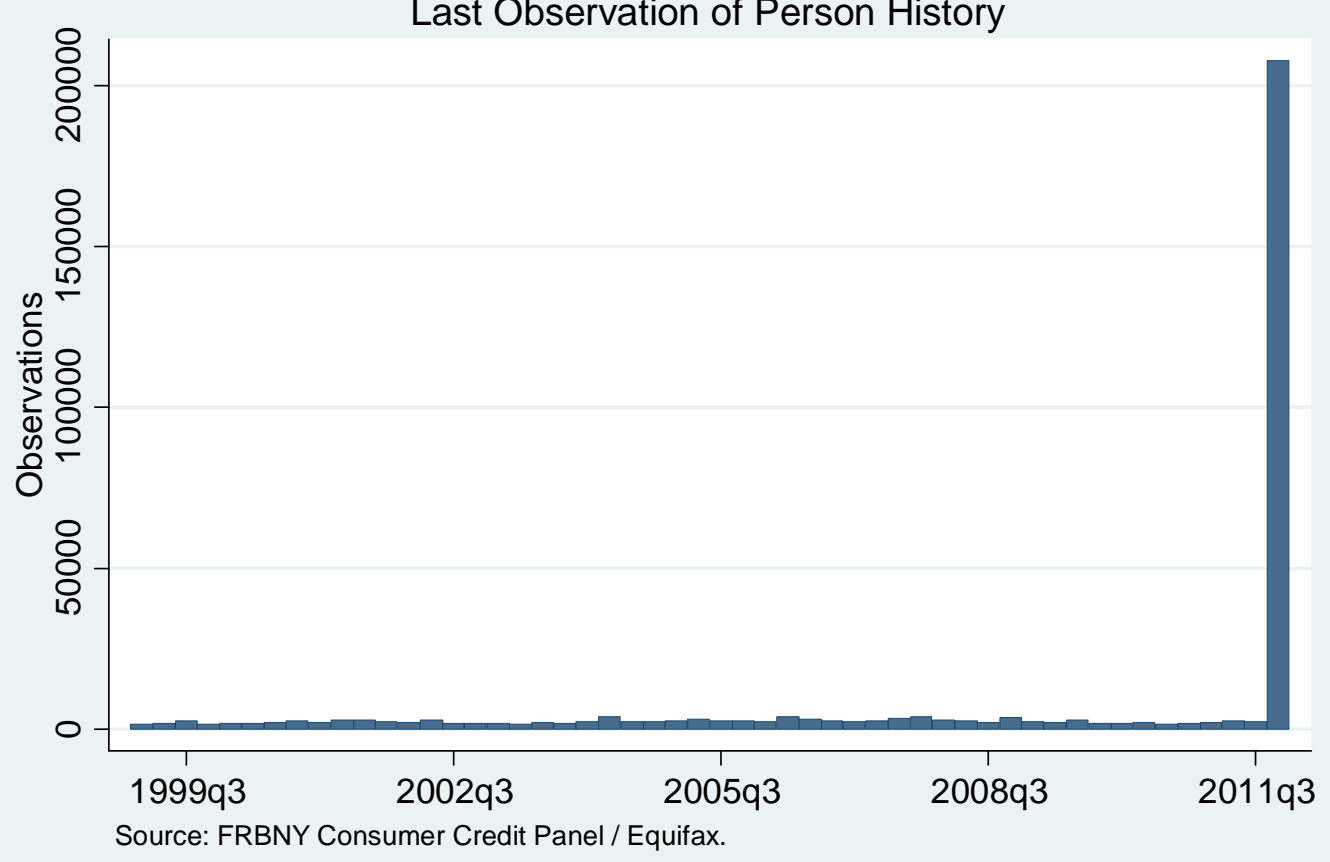




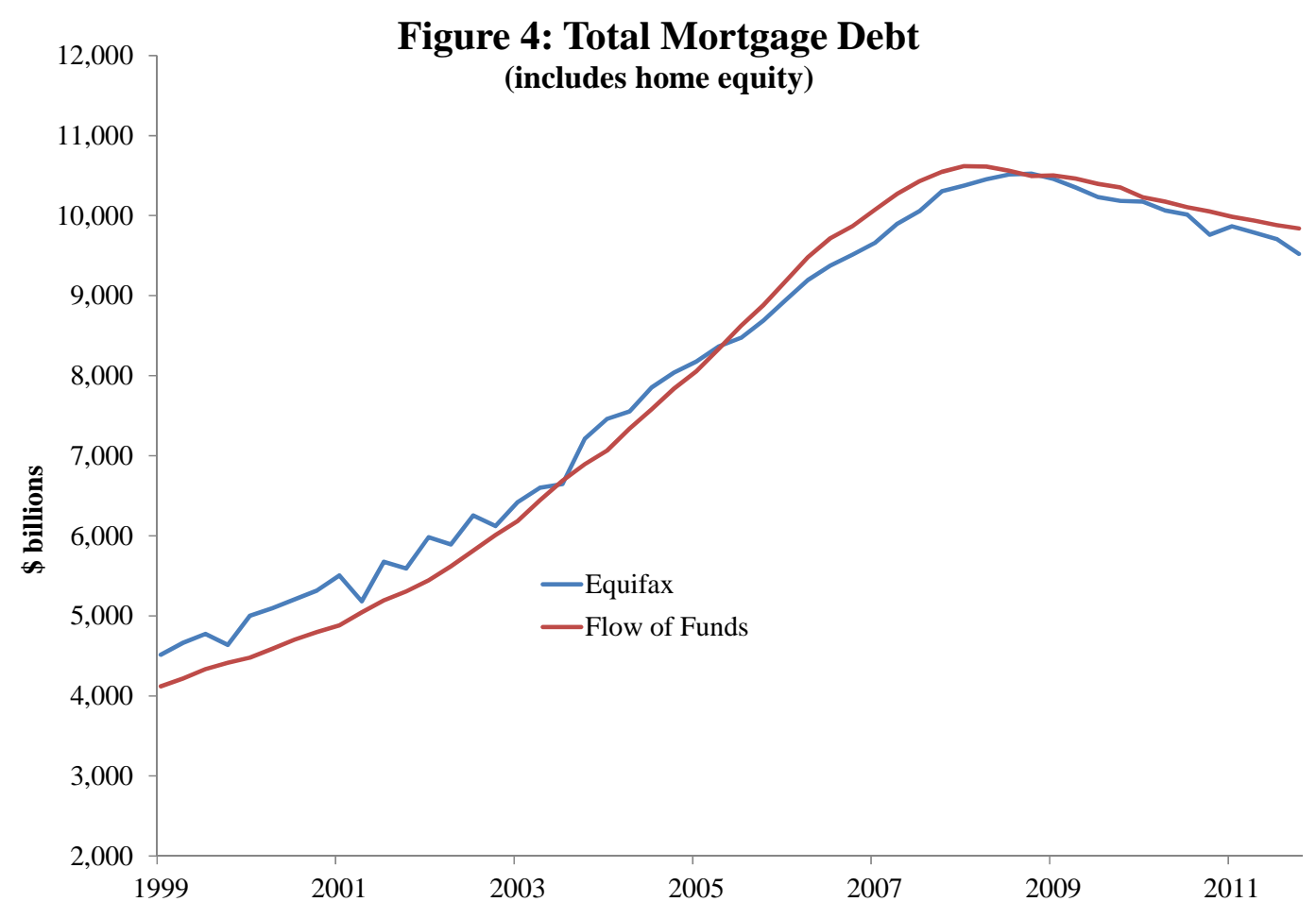

Source: Federal Reserve Board, FRBNY Consumer Credit Panel / Equifax.

Figure 5: Nonmortgage Debt

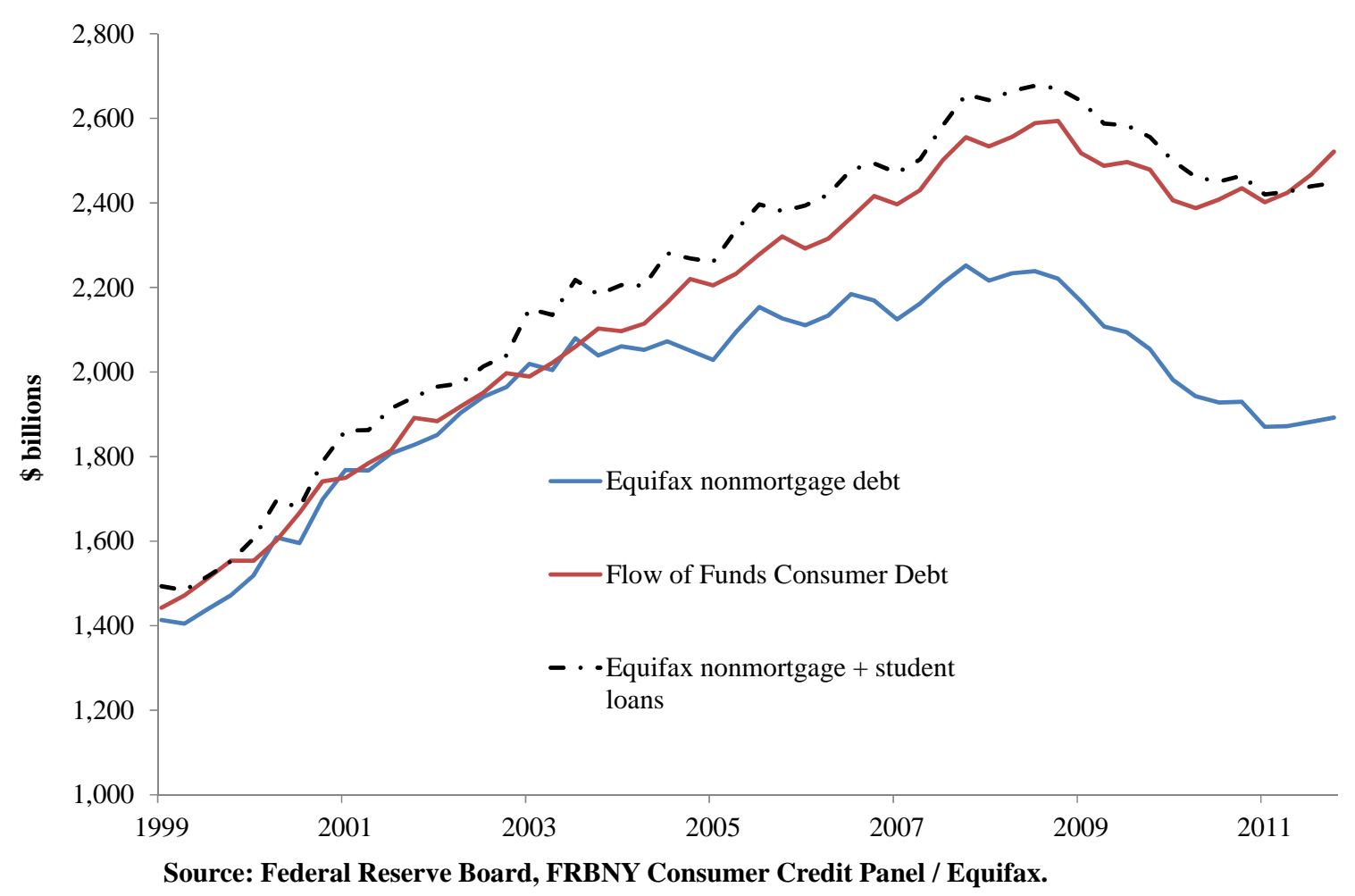


Figure 6

Fitted Nonmortgage Debt by County House Price Appreciation

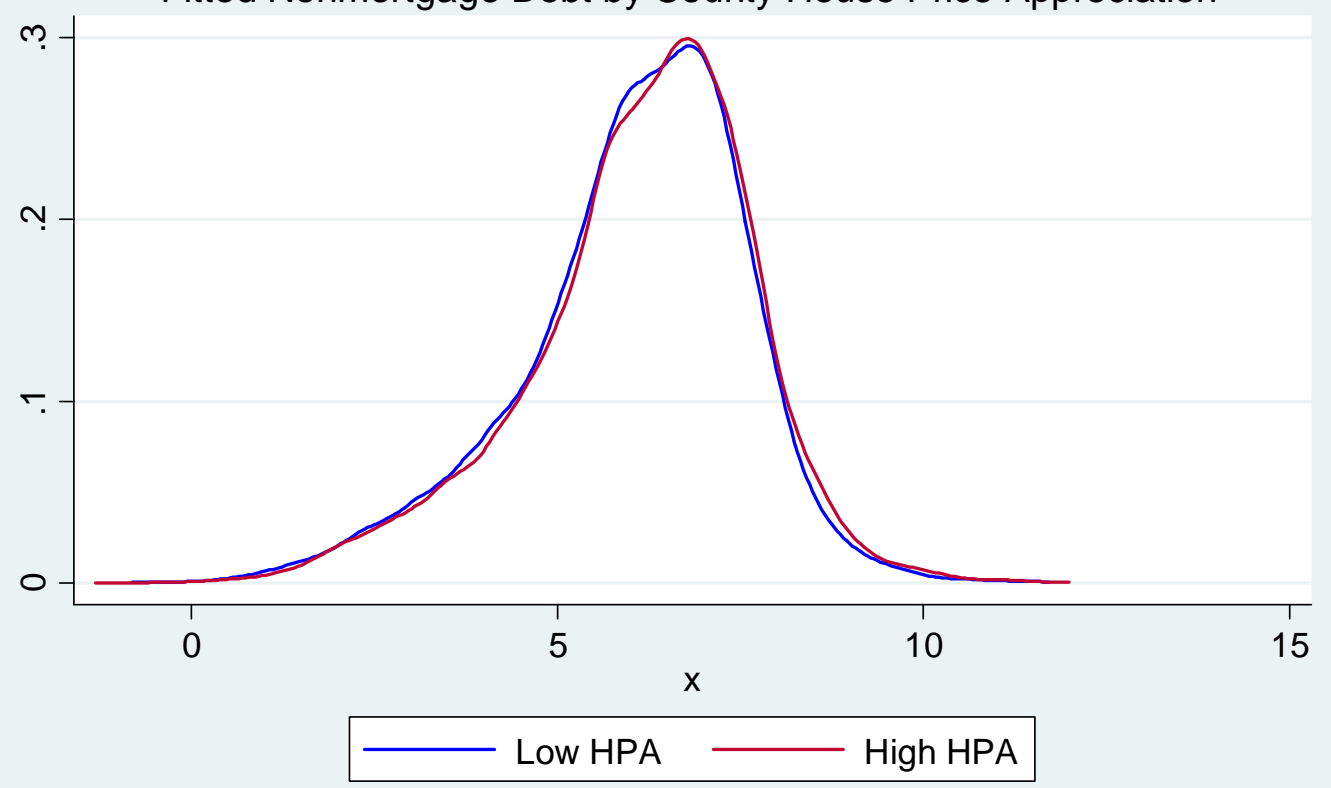

Source: FRBNY Consumer Credit Panel / Equifax, and CoreLogic.

Figure 7: County-level deciles of house price appreciation rates

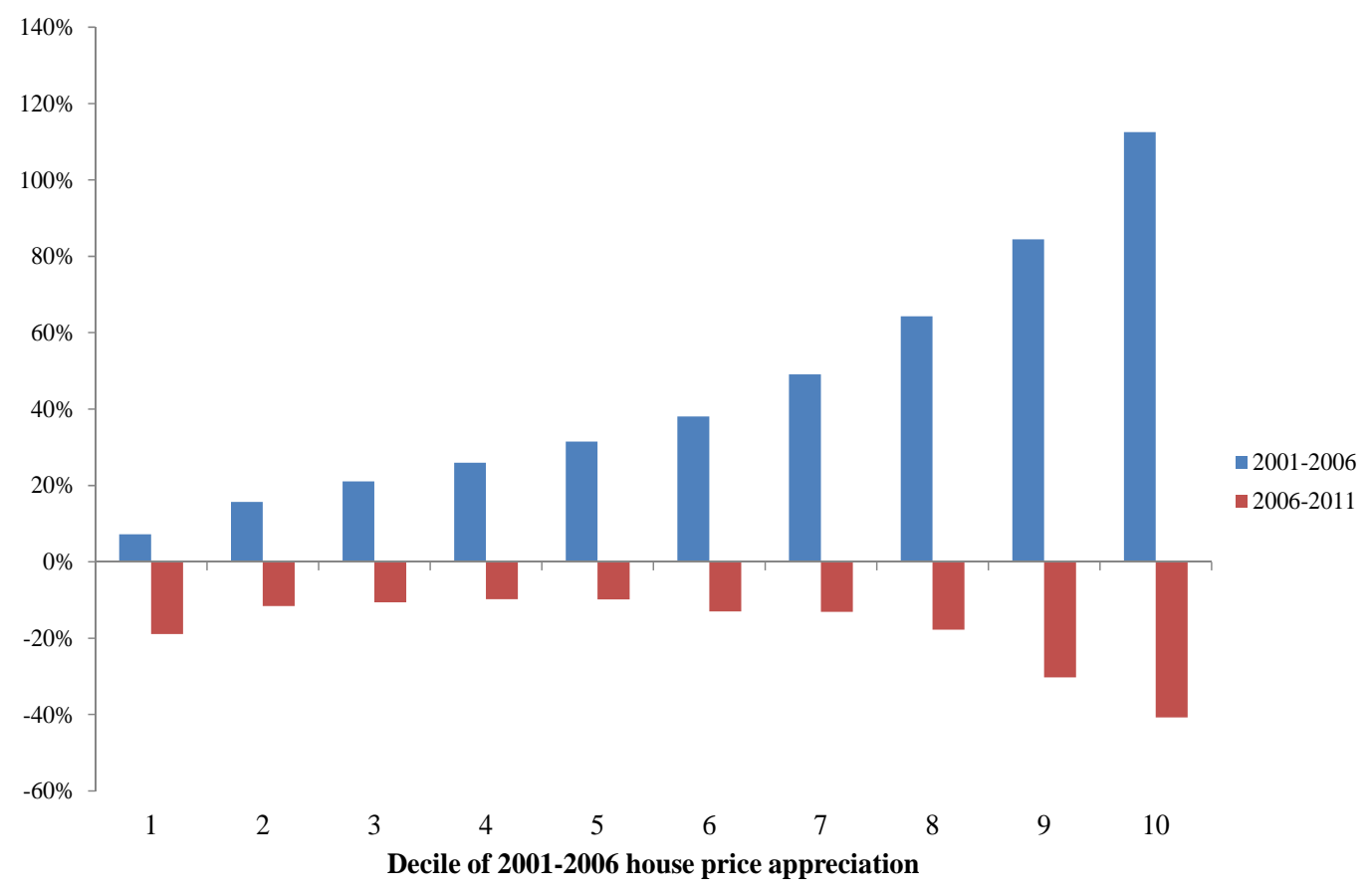

Source: CoreLogic 
Figure 8a: Probability living in high appreciation county: Homeowners blue $=$ do not live, red=do live

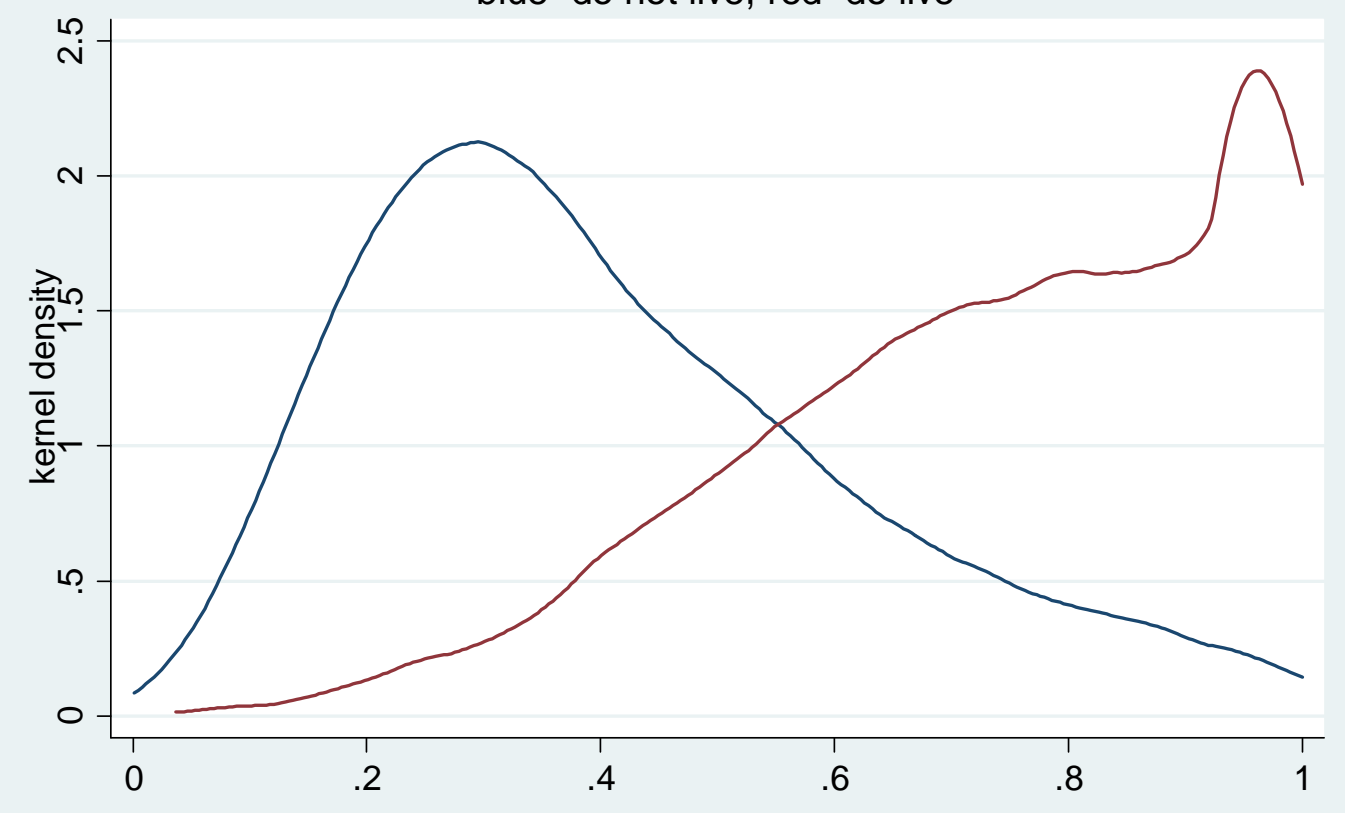

Source: FRBNY Consumer Credit Panel / Equifax. Conditioned on predicted total debt in 40th-60th pctile.

Figure 8b: Probability living in high appreciation county: Renters blue=do not live, red=do live

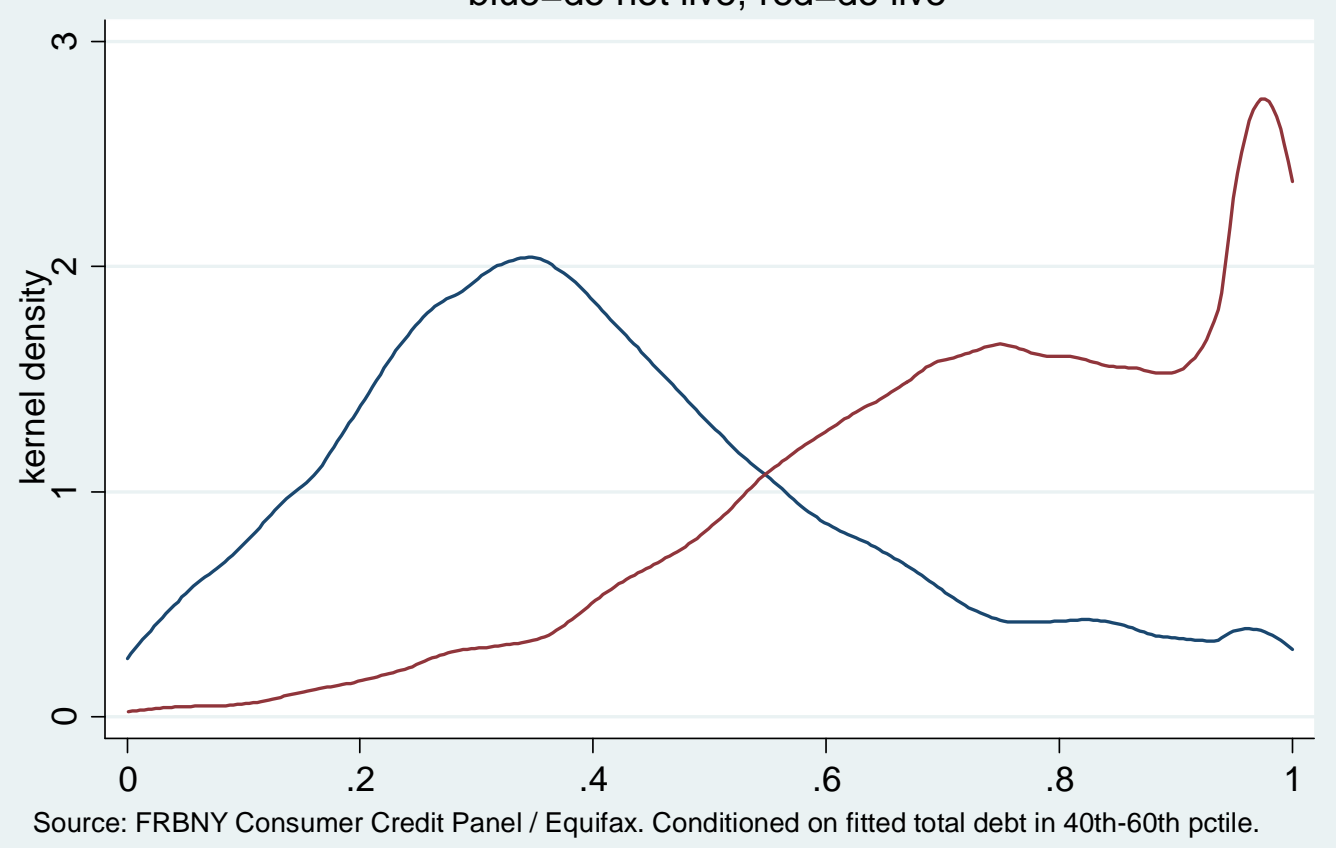

